\title{
Adiponectin Haploinsufficiency Promotes Mammary Tumor Development in MMTV-PyVT Mice by Modulation of Phosphatase and Tensin Homolog Activities
}

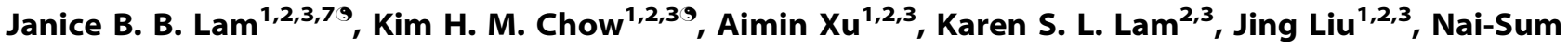 \\ Wong $^{4}$, Randall T. Moon ${ }^{6}$, Peter R. Shepherd ${ }^{8}$, Garth J. S. Cooper ${ }^{8}$, Yu Wang ${ }^{1,3,5 *}$
}

1 Department of Pharmacology and Pharmacy, University of Hong Kong, Hong Kong, China, 2 Department of Medicine, University of Hong Kong, Hong Kong, China, 3 Research Center of Heart, Brain, Hormone, and Healthy Aging, University of Hong Kong, Hong Kong, China, 4 Department of Biochemistry, University of Hong Kong, Hong Kong, China, 5 Open Laboratory of Chemical Biology of the Institute of Molecular Technology for Drug Discovery and Synthesis, University of Hong Kong, Hong Kong, China, $\mathbf{6}$ Howard Hughes Medical Institute, University of Washington School of Medicine, Seattle, Washington, United States of America, 7 School of Biological Sciences, University of Auckland, Auckland, New Zealand, 8 Maurice Wilkins Centre for Molecular Biodiscovery, University of Auckland, Auckland, New Zealand

\begin{abstract}
Background: Adiponectin is an adipokine possessing beneficial effects on obesity-related medical complications. A negative association of adiponectin levels with breast cancer development has been demonstrated. However, the precise role of adiponectin deficiency in mammary carcinogenesis remains elusive.

Methodology/Principal Findings: In the present study, MMTV-polyomavirus middle T antigen (MMTV-PyVT) transgenic mice with reduced adiponectin expressions were established and the stromal effects of adiponectin haploinsufficiency on mammary tumor development evaluated. In mice from both FVB/N and C57BL/6J backgrounds, insufficient adiponectin production promoted mammary tumor onset and development. A distinctive basal-like subtype of tumors, with a more aggressive phenotype, was derived from adiponectin haplodeficient MMTV-PyVT mice. Comparing with those from control MMTV-PyVT mice, the isolated mammary tumor cells showed enhanced tumor progression in re-implanted nude mice, accelerated proliferation in primary cultures, and hyperactivated phosphatidylinositol-3-kinase (PI3K)/Akt/beta-catenin signaling, which at least partly attributed to the decreased phosphatase and tensin homolog (PTEN) activities. Further analysis revealed that PTEN was inactivated by a redox-regulated mechanism. Increased association of PTEN-thioredoxin complexes was detected in tumors derived from mice with reduced adiponectin levels. The activities of thioredoxin (Trx1) and thioredoxin reductase (TrxR1) were significantly elevated, whereas treatment with either curcumin, an irreversible inhibitor of TrxR1, or adiponectin largely attenuated their activities and resulted in the re-activation of PTEN in these tumor cells. Moreover, adiponectin could inhibit TrxR1 promoter-mediated transcription and restore the mRNA expressions of TrxR1.
\end{abstract}

Conclusion: Adiponectin haploinsufficiency facilitated mammary tumorigenesis by down-regulation of PTEN activity and activation of PI3K/Akt signalling pathway through a mechanism involving Trx1/TrxR1 redox regulations.

Citation: Lam JBB, Chow KHM, Xu A, Lam KSL, Liu J, et al. (2009) Adiponectin Haploinsufficiency Promotes Mammary Tumor Development in MMTV-PyVT Mice by Modulation of Phosphatase and Tensin Homolog Activities. PLoS ONE 4(3): e4968. doi:10.1371/journal.pone.0004968

Editor: Nils Cordes, Dresden University of Technology, Germany

Received November 19, 2008; Accepted February 20, 2009; Published March 25, 2009

Copyright: (C) 2009 Lam et al. This is an open-access article distributed under the terms of the Creative Commons Attribution License, which permits unrestricted use, distribution, and reproduction in any medium, provided the original author and source are credited.

Funding: This work was supported by the grants from Seeding Funds for Basic Research of the University of Hong Kong (Y. Wang), Hong Kong Research Grant Council grants HKU 777908M (Y. Wang) and HKU 779707M (A. Xu), and the Area of Excellent Scheme (AoE/P-10-01) established under the University Grants Committee, HKSAR. Adiponectin knockout mice were kindly provided by Dr. Lawrence Chan at Baylor College of Medicine, who generated these mice with the support of the US National Institutes of Health grant HL-51586. The funders had no role in study design, data collection and analysis, decision to publish, or preparation of the manuscript.

Competing Interests: The authors have declared that no competing interests exist.

*E-mail: yuwanghk@hku.hk

9 These authors contributed equally to this work.

\section{Introduction}

The prevalence of obesity and obesity-related cancers has risen alarmingly for the past several decades $[1,2,3]$. Unfortunately, the mechanisms underlying the association between obesity and cancer are not well understood. Recent evidences suggest that adipokines, referring to a group of secreted factors from adipose tissue, could be the key players in regulating obesity-related carcinogenesis $[4,5,6,7]$. Adiponectin is an abundant adipocyte- derived hormone that can elicit pleiotropic beneficial functions against obesity-related medical conditions, such as diabetes, chronic inflammation, atherosclerosis and tumorigenesis [8,9]. Decreased circulating concentrations of adiponectin are associated with many obesity-related cancer diseases, including breast cancer, endometrial cancer, gastric cancer, colorectal cancer, renal cell carcinoma and prostate cancer $[10,11,12,13,14,15,16]$. Breast cancer represents the second leading cause of death among women. An inverse correlation of circulating adiponectin levels 
with breast cancer risk has been observed in both pre- and postmenopausal women, independent of body mass index and other known risk factors $[17,18,19,20,21,22,23,24]$. Moreover, mammary tumors arising in women with low serum adiponectin levels are more likely to show a biologically aggressive and poor prognosis phenotype. These epidemiological evidences suggest that reduced adiponectin expression might be causally involved in obesity-related carcinogenesis.

In line with these clinical findings, numerous experimental evidences support the role of adiponectin as an inhibitory factor for breast cancer development [25,26,27,28,29,30,31,32,33]. Adiponectin at physiological concentrations suppresses the proliferation and causes cell cycle arrest in both estrogen receptor (ER)negative and ER-positive human breast carcinoma cells. It inhibits insulin- and growth factors-stimulated growth of ER-positive breast cancer cells [28]. Adiponectin replenishment suppresses mammary tumorigenesis of MDA-MB-231 cells in nude mice [28]. Cell-type dependent signalling mechanisms have been suggested to mediate the growth inhibitory effects of adiponectin. In MCF-7 cells, adiponectin induces AMP-activated protein kinase (AMPK) phosphorylation and inactivates p42/p44 MAPkinase (ERK1/2) [29]. By contrast, the inhibitory effects of adiponectin on T47D cell growth are associated with inactivation of ERK1/2 but not AMPK or p38 MAPK $[18,28]$. In MDA-MB231 cells with ectopic ER over-expression, globular adiponectin inhibits cell proliferation by blocking JNK2 signalling [26]. In ERnegative MDA-MB-231 cells, adiponectin could modulate the glycogen synthase kinase-3beta (GSK3beta)/beta-catenin signaling pathway [28]. Prolonged treatment with adiponectin markedly reduces serum-induced phosphorylation of GSK3beta, decreases intracellular accumulation and nuclear translocation of betacatenin, and suppresses cyclin D1 expression. Despite of these progresses, whether adiponectin deficiency is a direct contributor to the pathogenesis of breast cancer remain elusive.

In this study, we investigated the effects of reduced adiponectin expression on mammary tumor development in MMTV-PyVT transgenic mice. Mice with reduced adiponectin expressions were established in both FVB/N and C57BL/6J backgrounds. Adiponectin haploinsufficiency significantly reduced tumor latency and promoted mammary tumor development in both female and male animals. The results demonstrated that inadequate adiponectin production might alter the stromal microenvironment towards more pro-proliferative and pro-tumorigenic in mammary tissue, by triggering the abnormal redox activities that led to the inhibition of tumor suppressor PTEN and hyperactivation of PI3K/Akt signaling pathways in mammary tumor cells.

\section{Results}

\section{Adiponectin haploinsufficiency promotes mammary tumor development in MMTV-PyVT mice}

We generated MMTV-PyVT transgenic mice with reduced adiponectin expressions in both $\mathrm{FVB} / \mathrm{N}$ and C57BL/6J backgrounds. PyVT transgenic mice with complete loss of the adiponectin alleles could not be born alive across all generations due to embryonic lethality. On the other hand, the knockout genotypes were found in male and female PyVT(-/-) litters. Therefore, mice with normal $\operatorname{Py} V T(+/-) / A D \mathcal{N}(+/+)$ and reduced $P y V T(+/-) / A D N(+/-)$ adiponectin expressions were used in the present study. The heterozygotes showed a 4-5 folds reduction of adiponectin levels (Figure 1), which were more relevant to those breast cancer patients with decreased adiponectin levels. Tumor development of these mice was closely monitored every 2-3 days. All mice carrying the PyVT transgene developed mammary tumors. Tumor onset was recorded as the age of the animal at which palpable abnormal masses were detected (Figure 2). The overall median age of tumor latency in $P y V T(+/-) / A D N(+/-)$ mice of FVB/N background were 58 days for female $(\mathrm{n}=20)$ and 115 days for male $(\mathrm{n}=23)$ mice respectively, which were significantly earlier than those of $P y V T(+/-) / A D N(+/+)$ mice (66 days for female and 133.5 days for male mice, $n=23$ and 24 respectively, $\mathrm{p}<0.0001)$. Similar phenomena were also observed in mice of C57BL/6J background. The overall median tumor latency of female and male adiponectin haplodeficient PyVT mice (66 and 114 days respectively, $\mathrm{n}=19$ ) was significantly reduced comparing with those of mice having normal adiponectin expression levels $(73$ and 137 days respectively, $\mathrm{n}=19, \mathrm{p}<0.0001)$. Tumor development was monitored twice per week up to 14 and 28 weeks for female and male mice respectively (Figure 3). No tumors were found in PyVT(-/-) mice up to 60 weeks, irrespective of their adiponectin levels. Tumor growth was significantly accelerated in both female and male adiponectin haplodeficient PyVT mice compared to $P y V T(+/-) / A D N(+/+)$ mice. At the time of sacrifice, the total wet weights of tumors in $P y V T(+/-) / A D N(+/-)$ mice was over 2-fold heavier than those with normal adiponectin expression levels (Table 1). The mean tumor weight of female $\mathrm{PyVT}$ mice of FVB/N background when sacrificed at $14 \mathrm{wks}$ of age was $9.889 \pm 3.189 \mathrm{~g}$ in $A D N(+/-)$ animals compared to $4.483 \pm 1.645 \mathrm{~g}$ in $A D \mathcal{N}(+/+)$ animals. Similarly, in male FVB/N PyVT mice sacrificed at $22 \mathrm{wks}$ of age, the mean tumor weight was $6.857 \pm 1.262 \mathrm{~g}$ in $A D \mathcal{N}(+/-)$ animals compared to that of $3.687 \pm 1.483 \mathrm{~g}$ in $A D \mathcal{N}(+/+)$ animals. On the other hand, although the wet weights of lung tissues in female and male PyVT(+/-) mice were heavier than those in non-transgenic PyVT (-/-) mice (data not shown), they were not significantly different between mice with reduced and normal adiponectin expressions.

\section{Distinct basal-like subtype of tumors in adiponectin haplodeficient PyVT mice}

Five subtypes of breast carcinoma with different outcomes, including luminal A, luminal B, HER2+/ER-, basal-like and normal breast-like, were revealed by microarray studies [42]. Luminal A and B are ER positive tumors, whereas the other three subtypes are ER negative. Our preliminary microarray analysis suggested that the molecular profiles of tumor cells derived from PyVT $(+/-) / A D N(+/-)$ mice were very different from those of PyVT (+/-)/ADN $(+/+)$ mice and could be clustered separately (data not shown). To further validate such an observation, gene markers associated with different tumor subtypes were quantified by real-time PCR analysis. In PyVT(+/-)/ADN(+/-) tumors, basal-like subtype genes, including KRT17, KRT5, MFGE 8 and FZD7, were significantly up-regulated, whereas HER2+/ERsubtype-related genes, ERBB2 and $M E D 1$, were dramatically down-regulated (Figure 4A). Histological analysis demonstrated typical morphologic features associated with the basal-like subtype, including markedly elevated geographic tumor necrosis, ribbonlike architecture associated with central necrosis, pushing margin of invasion, and stromal lymphocytic response in tumors from PyVT(+/-)/ADN(+/-) mice [43] (Figure 4B). We could not detect these morphological features in any of $P y V T(+/-) / A D N(+/$ +) mice or the original PyVT mice, which in contrast showed a well-structured and organized morphology, suggesting that the phenotype differences may not be tumor developmental stage dependent. Moreover, the protein levels of p53, a characteristic associated with tumors overexpressing ERBB2, was significantly higher in the $P y V T(+/-) / A D N(+/+)$ tumors comparing with PyVT (+/-)/ADN $(+/-)$ tumors (Figure $4 \mathrm{C})$. These and the above 


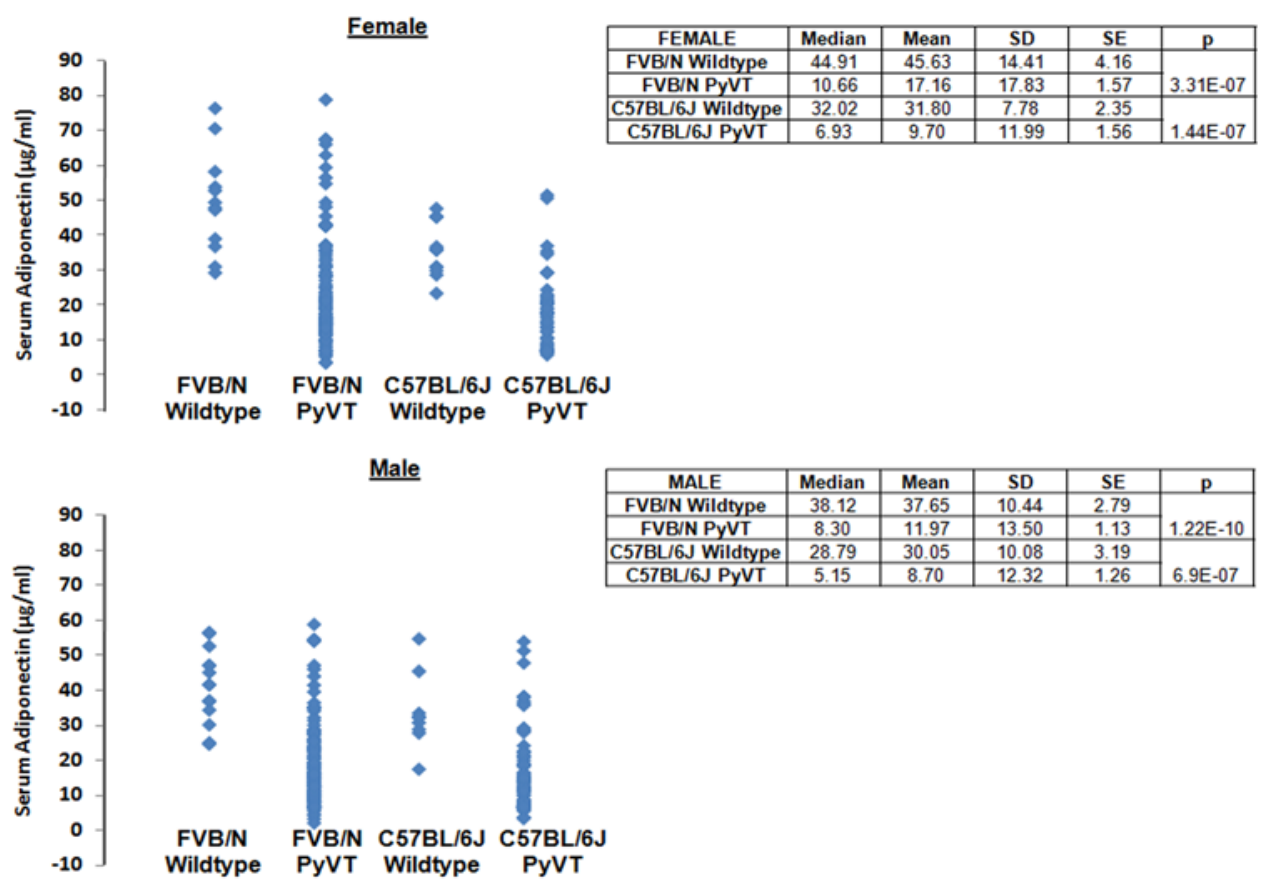

Figure 1. Serum adiponectin distributions in wildtype and PyVT mice. The serum adiponectin concentrations were measured by an inhouse sandwich ELISA assay using blood samples collected from the tail vein of FVB/N and C57BL/6J mice. The median and mean values were calculated and displayed in the table.

doi:10.1371/journal.pone.0004968.g001

evidence suggested that adiponectin deficiency might result in the development of a basal-like subtype tumor, which could be aroused from a different origin or subgroups of stem cells that developed tumor more aggressively.

\section{Accelerated growth of primary tumor cells derived from adiponectin haplodeficient mice}

We next isolated the primary tumor cells from the PyVT mice, and examined their tumor development in athymic nude mice following the protocol described previously [39]. Since tumors originated from different torso regions of PyVT mice might show various degrees of aggressiveness and onset latencies, we collected only tumors from the axillary mammary glands and re-implanted the isolated tumor cells into the posterior glands of athymic nude mouse by intraductal inoculation. The transplantation was reproducible and tumor growth rate correlated with the number of transplanted cells. Consistent with those observed in PyVT mice, the tumor development of cells derived from adiponectin haplodeficient mice was more aggressive than those from mice with normal adiponectin expressions (Figure 5, A and B). The accelerated tumor growth was reproducibly observed even when the cells were re-implanted for multiple times in new batches of nude mice (data not shown), suggesting that serial transplantation preserved the molecular characteristics of the tumor origin. At the time of sacrifice, the total weights of the collected tumors from PyVT(+/-)/ADN(+/-) mice were heavier than those of PyVT(+/ -) $/ A D \mathcal{N}(+/+)$ mice (Table 2). Note that when the tumor cells were exposed to physiological adiponectin secreted from adipocytes in the mammary tissue of nude mice, the change in the tumor volume was smaller, but still significantly different between $A D \mathcal{N}(+/-)$ with $A D \mathcal{N}(+/+)$ groups. At $\sim 3$ weeks after tumor occurrence, the measurable tumor volumes were 5.5 and 2.8 fold higher in $\mathrm{FVB} / \mathrm{N}$ male and female $P y V T(+/-) / A D N(+/-)$ animals respectively than those of $P y V T(+/-) / A D N(+/+)$ mice
(Figure 3), whereas the differences for the implanted nude mice were approximately 3.2 and 2.1 fold for male and female tumor cells respectively (Figure 5). The results further suggest that the magnitude of tumor growth could be suppressed in the presence of endogenous expression of adiponectin by adipocytes. The lung tissues of mice implanted with male tumor cells showed elevated wet weights than those implanted with female tumor cells. Moreover, there was a significant difference between the two nude mice groups implanted with male $P y V T(+/-) / A D \mathcal{N}(+/+)$ and $P y V T(+/-) / A D N(+/-)$ tumor cells, with much higher lung weights in the later group (Table 2). Massive lumps of metastatic tumor mass could be seen on the surface of the lungs from nude mice implanted with male PyVT(+/-)/ADN $(+/-)$ tumor cells. Hematoxylin and eosin staining confirmed that the metastatic capacities of these tumor cells were much higher than those from other groups (Figure 6).

We next compared the proliferation of the isolated primary tumor cells in culture by using $\left[{ }^{3} \mathrm{H}\right]$-thymidine incorporation assay (Figure 5, G and D). Cells derived from PyVT $(+/-) / A D N(+/-)$ mice showed dramatically enhanced DNA synthesis under both $0.5 \%$ FBS and 10\% FBS DMEM culture conditions. Moreover, the fold changes of $\left[{ }^{3} \mathrm{H}\right]$-thymidine incorporation between the two time points $(24 \mathrm{hr}$ and $48 \mathrm{hr}$ ) in $A D \mathcal{N}(+/-)$ group were greater than those of $A D \mathcal{N}(+/+)$ group. Similar results were also obtained by crystal violet staining and cell number counting (data not shown). These data demonstrated that tumor cells derived from adiponectin haplodeficient mice were more aggressive, and their intrinsic properties were well preserved even under conditions without any hormonal interference.

\section{Elevated $\mathrm{PI} 3 \mathrm{~K} / \mathrm{Akt} /$ beta-catenin signalling in tumor cells derived from adiponectin haplodeficient mice}

We previously reported that chronic treatment of adiponectin could modulate GSK3beta/beta-catenin pathway in MDA-MB- 
Female

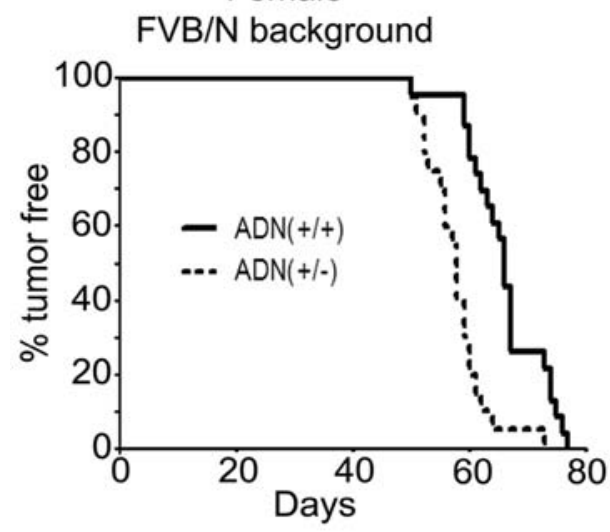

Female

C57BL/6J background

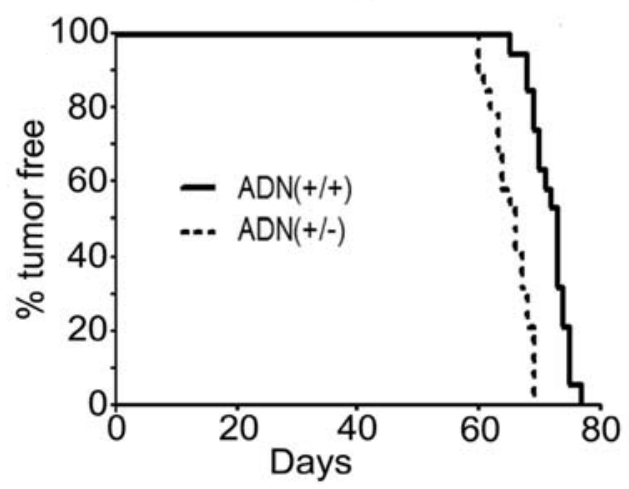

Male

FVB/N background

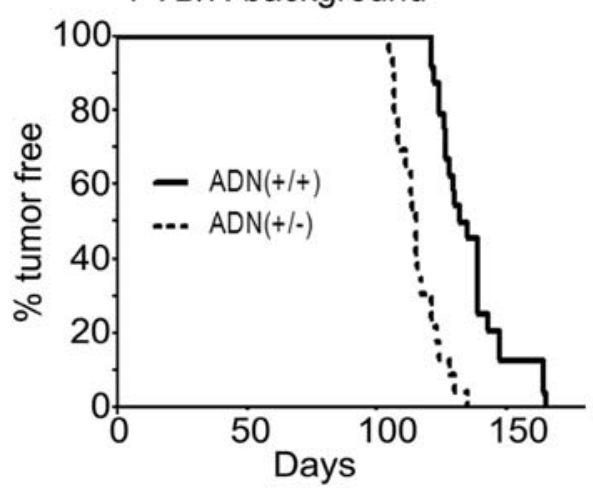

Male

C57BL/6J background

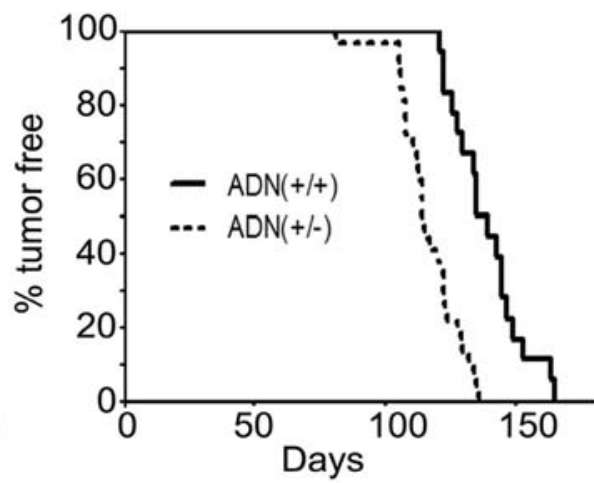

\begin{tabular}{|c|c|c|c|c|c|}
\hline & \multicolumn{3}{|c|}{ Median tumor latency (Days) } & \multirow[b]{2}{*}{ Risk ratio } & \multirow[b]{2}{*}{$95 \% \mathrm{Cl}$} \\
\hline & $A D N(+/+)$ & $\operatorname{ADN}(+/-)$ & $P$ & & \\
\hline FVB/N Female & $66.00(n=23)$ & $58.00(n=20)$ & $<0.0001$ & 0.1562 & $0.06935-0.3518$ \\
\hline FVB/N Male & $133.5(n=24)$ & $115.0(n=23)$ & $<0.0001$ & 0.1047 & $0.04717-0.2324$ \\
\hline C57BL/6J Female & $73.00(n=19)$ & $66.00(n=19)$ & $<0.0001$ & 0.08873 & $0.03554-0.2216$ \\
\hline C57BL/6J Male & $137.0(n=19)$ & $114.0(n=19)$ & $<0.0001$ & 0.1810 & $0.09269-0.3533$ \\
\hline
\end{tabular}

Figure 2. Reduced tumor latency in adiponectin haplodeficient MMTV-PyVT mice of both FVB/N and C57BL/6J genetic backgrounds. The tumor onset was closely monitored by visual inspection and palpation every 2-3 days. Latency of mammary tumors was defined as the age when a palpable lump was first detected in the mammary gland. Kaplan-Meier estimates of the tumor-free survival curves were calculated and plotted. Median value represents the time point when $50 \%$ of animals developed palpable tumor masses. The significance of differences in latency was analyzed by the Log-rank test. The comparisons were performed between $A D N(+/+)$ and $A D N(+/-)$ female (left panel) and male (right panel) animals in FVB/N and C57BL/6J genetic backgrounds. Cl, confidence interval.

doi:10.1371/journal.pone.0004968.g002

231 human breast cancer cells [28]. To investigate whether adiponectin inadequacy could enhance beta-catenin signaling in mammary tumors, we examined the phosphorylation status of GSK3beta and its upstream protein kinase Akt, as well as the protein levels and nuclear activities of beta-catenin (Figure 7A). The results revealed that in primary tumor cells derived from PyVT(+/-)/ADN(+/-) mice, phosphorylations of both Akt at serine 473 and GSK3beta at serine 9 were significantly increased.
On the other hand, the phosphorylation of ERK1/2 was not different between the two types of tumor cells from PyVT(+/-)/ $A D N(+/+)$ and $P y V T(+/-) / A D N(+/-)$ mice (data not shown). The protein levels of beta-catenin and its target cyclin D1 were largely elevated. The augmented beta-catenin signaling was also confirmed by measuring its nuclear activities, which were increased by $\sim 4.5$ folds in $P y V T(+/-) / A N D(+/-)$ tumor cells according to the results from the TOPflash/FOPflash reporter 

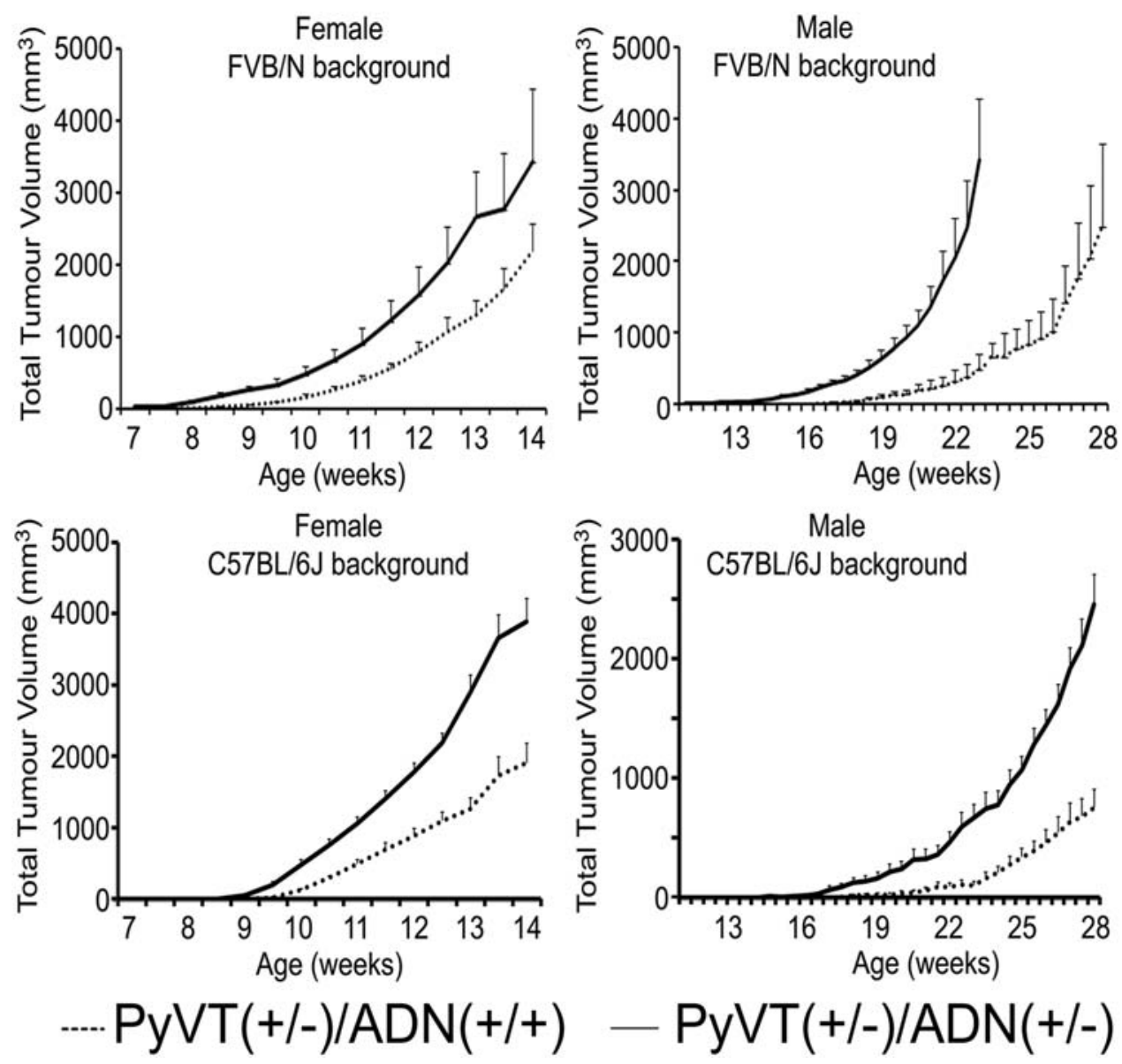

Figure 3. Accelerated mammary tumor development in adiponectin haplodeficient MMTV-PyVT mice. Tumor growth in PyVT(+/-)/ $A D N(+/+)$ and PyVT(+/-)/ADN(+/-) mice were monitored starting from 6 and $11 \mathrm{wks}$, up to 14 and 28 wks for female (left panel) and male (right panel) mice respectively. Tumor sizes were measured using vernier calipers and tumor volume calculated as described in Methods. Each group contained 13-20 mice, and the mean tumor volume \pm SD was presented. doi:10.1371/journal.pone.0004968.g003

assays (Figure 7A). Inappropriate Akt activation can occur through PI3K. We found that the protein levels of the pl10alpha subunits of PI3K, the main isoform involved in oncogenesis, were slightly increased in PyVT(+/-)/ADN(+/-) tumor cells (data not shown). Both general (LY294002) and selective pharmacological antagonists against different isoforms of pl10 catalytic subunits (p1 10alpha-selective inhibitor PIK75, p1 10beta-selective inhibitor TGX221 and p110delta-selective inhibitor IC8714) [34] were then used for testing their effects in cells isolated from $P y V T(+/-) /$
$A D \mathcal{N}(+/-)$ tumors. Treatment with either LY294002 or PIK75 led to significantly attenuated phosphorylations of Akt and GSK3beta and more than $50 \%$ reductions of nuclear beta-catenin activities, whereas treatment with IC8714 and TGX221 did not have much impacts (Figure 7B). Similarly, treatment with a specific inhibitor of Akt1 and Akt2 (Akti-1/2) significantly reduced beta-catenin and cyclin-D1 expression levels and caused about 11fold decrease of nuclear beta-catenin activities (Figure 7G). To further verify the involvement of PI3K and Akt in the accelerated

Table 1. Total wet weights of tumor and lung tissues collected from $\operatorname{PyVT}(+/-) / A D N(+/+)$ and $P y V T(+/-) / A D N(+/-)$ mice in $\mathrm{FVB} / \mathrm{N}$ and C57BL/6J background.

\begin{tabular}{|c|c|c|c|c|c|c|c|c|}
\hline & \multicolumn{4}{|l|}{ FVB/N } & \multicolumn{4}{|l|}{ C57BL/6J } \\
\hline & \multicolumn{2}{|c|}{ Female (14 weeks) } & \multicolumn{2}{|l|}{ Male (22 Weeks) } & \multicolumn{2}{|l|}{ Female (16 weeks) } & \multicolumn{2}{|l|}{ Male (26 Weeks) } \\
\hline & $A D N(+/+)(\mathrm{n}=20)$ & $\begin{array}{l}A D N(+/-) \\
(\mathrm{n}=\mathbf{2 0})\end{array}$ & $A D N(+/+)(\mathrm{n}=13)$ & $\begin{array}{l}A D N(+/-) \\
(\mathbf{n}=\mathbf{1 8})\end{array}$ & $A D N(+/+)(\mathrm{n}=13)$ & $\begin{array}{l}A D N(+/-) \\
(\mathrm{n}=19)\end{array}$ & $A D N(+/+)(\mathrm{n}=18)$ & $\begin{array}{l}A D N(+/-) \\
(\mathrm{n}=18)\end{array}$ \\
\hline Tumor & $4.483 \pm 1.645$ & $9.889 \pm 3.189 *$ & $3.687 \pm 1.483$ & $6.857 \pm 1.262^{*}$ & $3.609 \pm 1.846$ & $8.704 \pm 2.742^{*}$ & $2.134 \pm 1.253$ & $5.079 \pm 2.51^{*}$ \\
\hline Lung & $0.203 \pm 0.041$ & $0.213 \pm 0.0309$ & $0.252 \pm 0.005$ & $0.286 \pm 0.028$ & $0.225 \pm 0.085$ & $0.219 \pm 0.026$ & $0.266 \pm 0.018$ & $0.292 \pm 0.029$ \\
\hline
\end{tabular}

${ }^{*} \mathrm{p}<0.05$ vs the corresponding PyVT(+/-)/ADN(+/+) mice group.

doi:10.1371/journal.pone.0004968.t001 


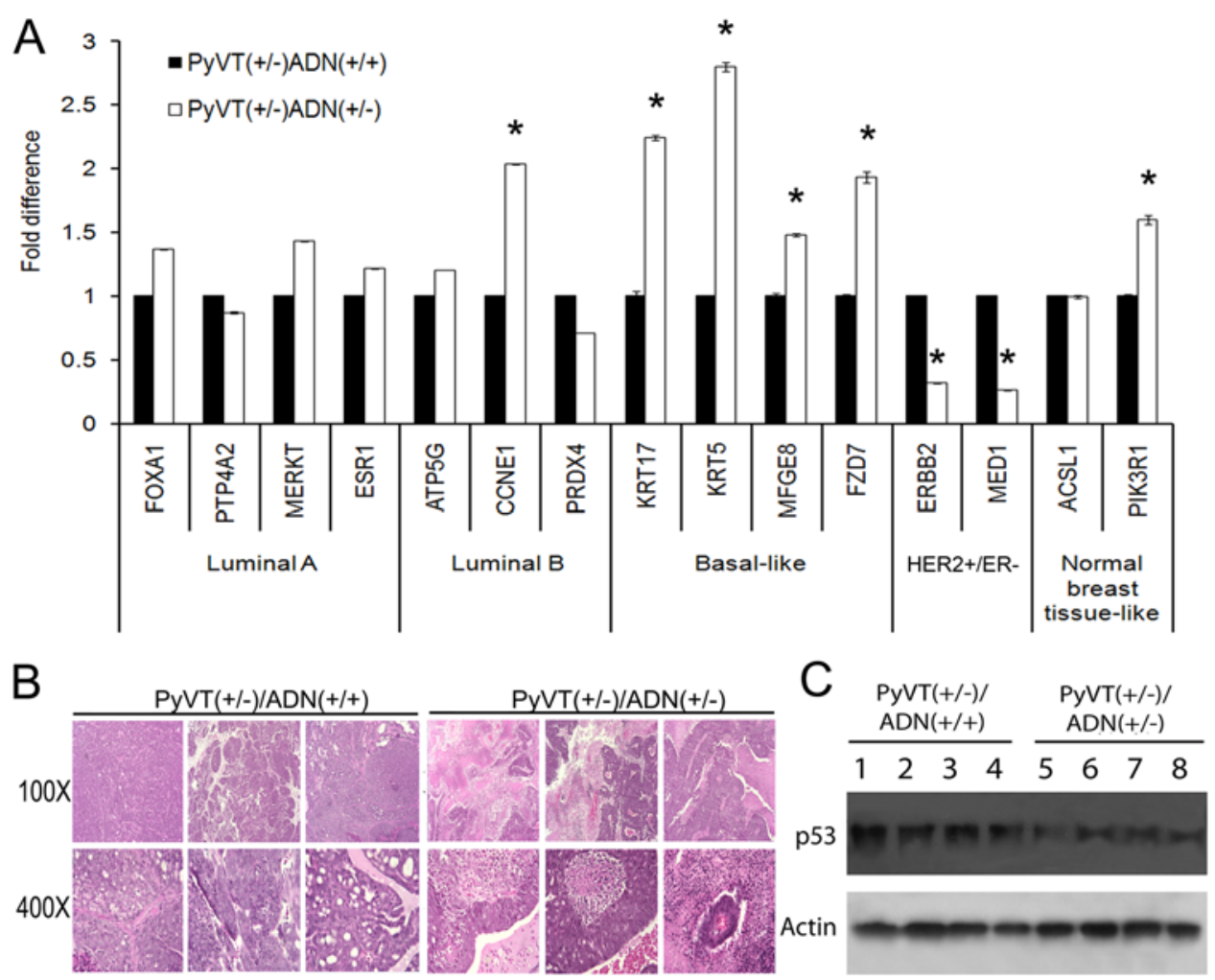

Figure 4. A basal-like subtype of mammary tumors derived from adiponectin haplodeficient MMTV-PyVT mice. A, Quantitative RT-PCR analysis of the expression levels of gene markers associated with different subtypes of breast tumors. The RNA was extracted from cultured primary tumor cells isolated from 14-week old PyVT(+/-)/ADN(+/+) and PyVT(+/-)/ADN(+/-) female FVB/N mice and quantitative PCR analysis performed as described in the Methods. *, $\mathrm{P}<0.01$ vs PyVT(+/-)/ADN(+/+) group, $\mathrm{n}=10 . B$, Morphological features of tumors derived from 14-week old female PyVT(+/-)/ADN(+/+) and PyVT(+/-)/ADN(+/-) mice of the FVB/N background. Distinct morphologies were observed between tumors collected from mice with normal and reduced adiponectin levels. Note that central necrosis and geographic tumor necrosis, as well as stromal lymphocytic responses represented the typical basal-like subtype of breast tumors in PyVT(+/-)/ADN(+/-) mice. $C$, The protein levels of p53 were much higher in tumors derived from PyVT(+/-)/ADN(+/+) mice compared to those of the PyVT(+/-)/ADN(+/-) mice as measured by Western Blotting using specific antibodies purchased from Cell Signaling Biotechnology.

doi:10.1371/journal.pone.0004968.g004

proliferation of tumor cells derived from PyVT (+/-)/ADN $(+/-)$ mice, their inhibitors were used for cell proliferation measurement using $\left[{ }^{3} \mathrm{H}\right]$-thymidine incorporation assay. Importantly, the general inhibitor LY294002 and Akti-1/2 showed greater extent of attenuation on the cell growth at all time points, whereas the p110alpha-selective inhibitor PIK75 was more potent than the other two inhibitors (Figure 7D), suggesting that blockade of PI3K or Akt reversed the proliferative advantage of adiponectin haplodeficient tumors. Adiponectin treatment significantly attenuated phosphorylations of Akt and GSK3beta and beta-catenin protein levels and nuclear activities, as well as inhibited cell proliferation to a greater extent in $P y V T(+/-) / A D N(+/-)$ tumor cells (Figure 8). On the other hand, it had little effects on p110alpha levels. These results implicated that the activation of PI3K/Akt pathway might contribute to the elevated beta-catenin signalling cascades in adiponectin haplodeficient mammary tumors.

\section{Decreased PTEN activities caused by altered redox environment in adiponectin haplodeficient PyVT tumors \\ PTEN is one of the most frequently mutated tumor suppressors that can prevent the activation of the cell survival PI3K/Akt signaling pathway [44]. In the absence of PTEN function, cells exhibit elevated Akt activities. It has been reported that PTEN could bind to Trxl in the cytosol, resulting in a functional loss of}

its lipid phosphatase and membrane binding activity [45]. Interestingly, PTEN activities were decreased by more than $50 \%$ in PyVT (+/-)/ADN $(+/-)$ tumor cells (Figure 9A), whereas its total protein amount was not significantly different (Figure 9B). The activities of both Trxl and its upstream binding enzyme, TrxRl, were augmented by nearly $40 \%$ in $P y V T(+/-) / A D \mathcal{N}(+/$ -) tumor cells (Figure 9A). While the protein levels of Trxl were similar between PyVT(+/-)/ADN $(+/+)$ and PyVT(+/-)/ADN $(+/$ -) tumors, the total amount of TrxR1 was increased in PyVT + / $-) / A D \mathcal{N}(+/-)$ tumor cells (Figure $8 \mathrm{~B})$. Surprisingly, co-immunoprecipitation experiment revealed that the amounts of Trx1-bound PTEN were dramatically increased in tumor cells derived from the adiponectin haplodeficient $P y V T(+/-)$ mice (Figure 9C). Treatment with curcumin, an irreversible inhibitor of TrxR1 (40), elevated PTEN activity by nearly 3 folds in $P y V T(+/-) / A D \mathcal{N}(+/$ -) tumor cells, which was accompanied by the decreased activities of both TrxR1 and Trxl (Figure 9A). A stimulatory effect on PTEN activity was also observed in cells treated with adiponectin (Figure 9A). In PyVT(+/-)/ADN(+/-) tumor cells, the TrxR1 promoter-driven reporter activity was $\sim 1.8$ fold higher than that of PyVT (+/-)/ADN $(+/+)$ tumor cells (Figure 9D). Treatment with adiponectin for $24 \mathrm{hrs}$ significantly reduced the reporter activities by $\sim 60 \%$ in $P y V T(+/-) / A D \mathcal{N}(+/-)$ tumor cells but had no significant effects on PyVT $(+/-) / A D \mathcal{N}(+/+)$ tumor cells. Similar effects were also observed for TrxR1 mRNA levels in tumor cells treated with or without adiponectin (Figure 9D). Taken together, 

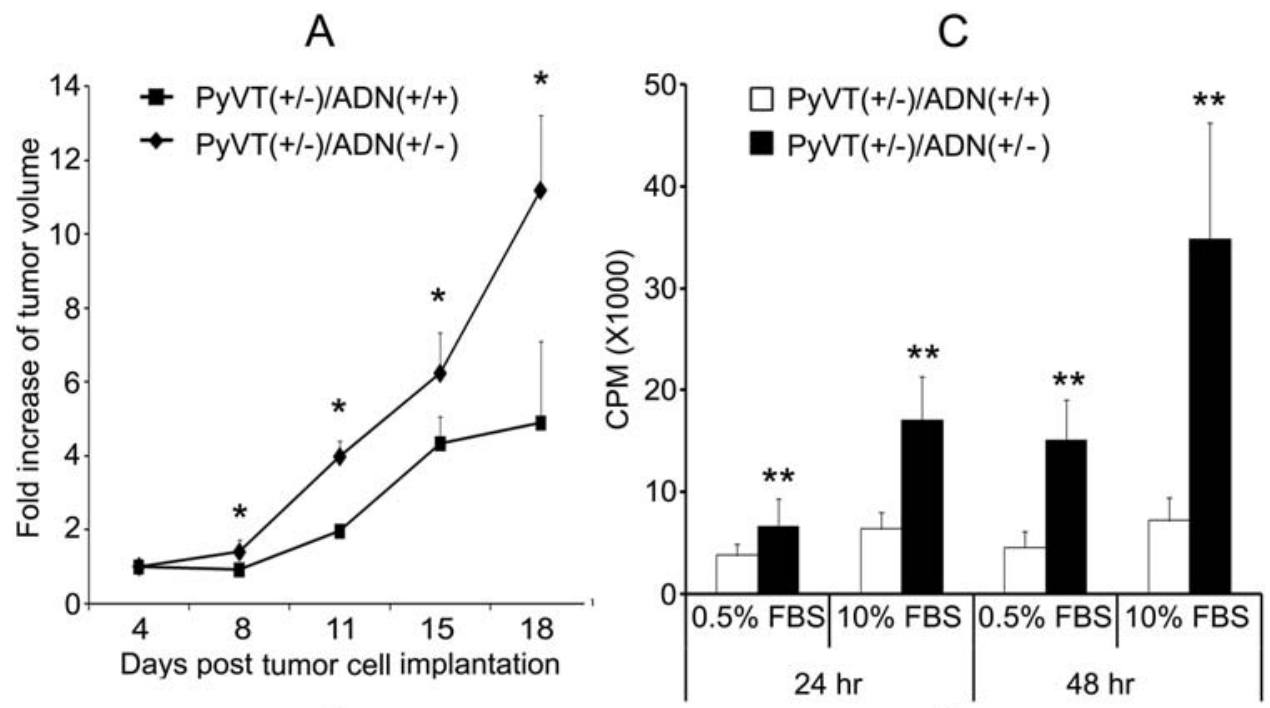

B
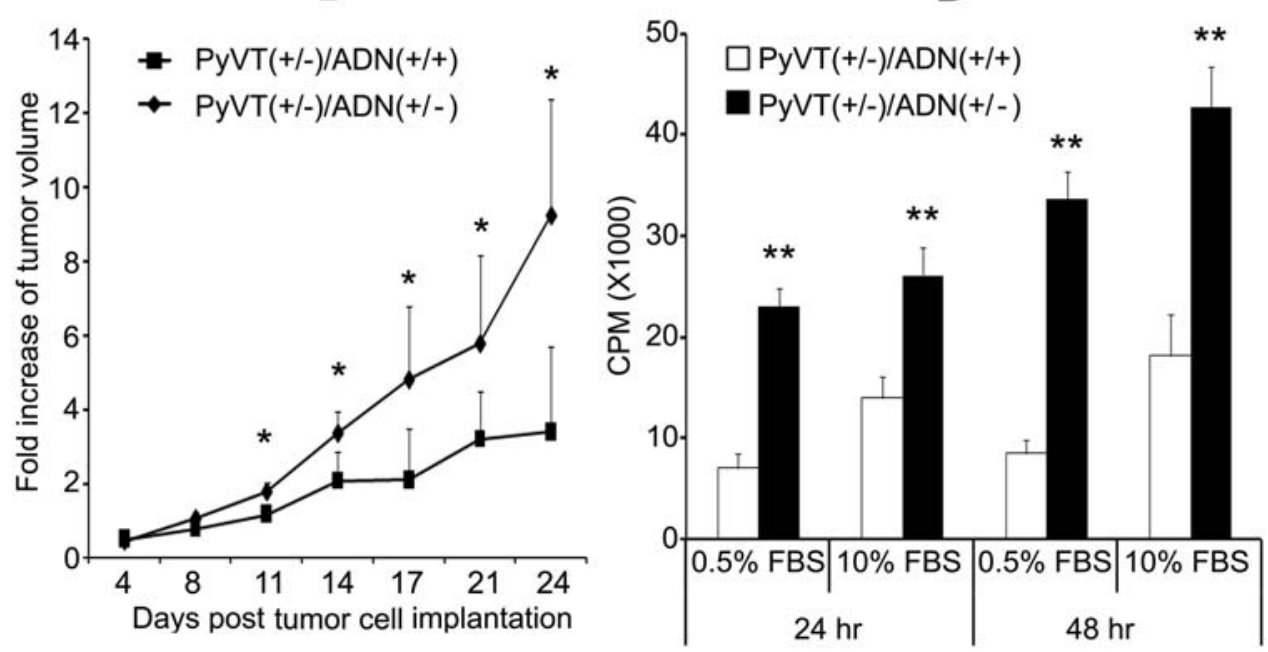

Figure 5. Mammary tumor cells derived from adiponectin haplodeficient mice were more aggressive. Primary mammary tumor cells were isolated from FVB/N PyVT mice with normal $[P y V T(+/-) / A D N(+/+)]$ or reduced $[P y V T(+/-) / A D N(+/-)]$ adiponectin expressions, and implanted into nude mice for assessing their tumor development in vivo (A and $\mathrm{B}$ ), or subjected to culture and $\left[{ }^{3} \mathrm{H}\right]$-thymidine incorporation assays for evaluating their proliferations in vitro ( $C$ and $D)$. The comparison between $P y V T(+/-) / A D N(+/+)$ and PyVT(+/-)/ADN(+/-) groups were performed for tumor cells derived from both female $(A$ and $C)$ and male $(B$ and $D)$ mice. Tumor growth was presented as the fold changes of tumor volume against the first measurement at day 4 ( $A$ and B). DNA synthesis was monitored in $0.5 \%$ and 10\% FBS culture conditions at 24 and 48 hrs after seeding (C and D). CPM, counts per minute. ${ }^{*}, \mathrm{P}<0.05$ and ${ }^{*}, \mathrm{P}<0.01$ vs corresponding groups ( $\left.\mathrm{n}=13-18\right)$.

doi:10.1371/journal.pone.0004968.g005

these results suggested that in tumor cells derived from adiponectin haplodeficient mice, the increased TrxR1/Trxl redox activities might be involved in inactivation of PTEN and hyperactivation of PI3K/Akt signalling pathways.

\section{Discussion}

Although the anti-tumor activities of adiponectin have been suggested by numerous clinical and experimental evidences, the underlying mechanisms remain to be established. Here, we have evaluated the impacts of reduced adiponectin expression on mammary tumor development in MMTV-PyVT mice. Our results demonstrate that in both $\mathrm{FVB} / \mathrm{N}$ and $\mathrm{C} 57 \mathrm{BL} / 6 \mathrm{~J}$ genetic backgrounds, adiponectin inadequacy is associated with earlier tumor onset and accelerated tumor growth (Figure 2, Figure 3 and Table 1). The aggressive phenotypes of tumor cells derived from $P y V T(+/-) / A D \mathcal{N}(+/-)$ mice are retained during serial trans-implantations in nude mice as well as multiple passages in culture (Figure 5), suggesting that insufficient adiponectin production from adipose tissue might result in an abnormal microenvironment that leads to distinct but permanent genetic and phenotypic modifications of mammary epithelial cells. Indeed, both histological and gene expression analyses suggest a distinct basal-like subtype of tumors in $P y V T(+/-) / A D N(+/-)$ mice (Figure 4). Tumor cells derived from adiponectin haplodeficient mice show enhanced beta-catenin nuclear activities and protein stabilities, which might be partly attributed to the hyperactivated PI3K/Akt signaling (Figure 7). While adiponectin treatment restores most of the changes downstream of PI3K, including Akt and GSK3beta and beta-catenin, it has little effects on pll0alpha (Figure 8). On the other hand, adiponectin deficiency causes inactivation of PTEN and results in the hyper-activated PI3K/Akt signaling in $P y V T(+/-) / A D N(+/-)$ tumors (Figure 9). 
Table 2. Total net weights $(\mathrm{g})$ of tumor and lung tissues collected from nude mice implanted with primary tumor cells isolated from female and male PyVT(+/-)/ADN(+/+) and PyVT(+/-)/ADN(+/-) mice.

\begin{tabular}{|c|c|c|c|c|}
\hline & \multicolumn{4}{|l|}{ Nude mice } \\
\hline & \multicolumn{2}{|c|}{ Female (18 days after implantation) } & \multicolumn{2}{|c|}{ Male (24 days after implantation) } \\
\hline & $A D N(+/+)(\mathrm{n}=17)$ & $A D N(+/-)(\mathrm{n}=13)$ & $A D N(+/+)(\mathrm{n}=13)$ & $A D N(+/-)(\mathrm{n}=18)$ \\
\hline Tumor & $0.503 \pm 0.262$ & $0.875 \pm 0.693^{*}$ & $0.449 \pm 0.366$ & $0.831 \pm 0.425^{*}$ \\
\hline Lungs & $0.160 \pm 0.063$ & $0.174 \pm 0.014$ & $0.187 \pm 0.0407$ & $0.248 \pm 0.0928^{*}$ \\
\hline
\end{tabular}

${ }^{*} \mathrm{p}<0.05$ vs the corresponding PyVT(+/-)/ADN(+/+) mice group.

doi:10.1371/journal.pone.0004968.t002

PTEN/PI3K/Akt constitutes an important pathway regulating the signaling of multiple biological processes such as apoptosis, metabolism and cell proliferation [46]. PTEN activity is lost by mutations, deletions, promoter methylation silencing, or protein modifications at high frequency in many primary and metastatic human cancers [47]. Hyperactivation of the PI3K/Akt signaling pathway triggered by PTEN inactivation has been found to correlate with increased breast cancer risks, poor prognosis and resistance to hormone therapy [44]. In adiponectin haplodeficient PyVT tumors, while the total protein levels of PTEN are not altered, its activities are significantly decreased (Figure 9). PTEN is well-known to be regulated by the redox state of the active site cysteine residues [48]. Oxidation of PTEN resulted from thiol modification leads to reversible inhibition of its phosphatase activity. The thioredoxin system, composed of TrxR, Trx, and NADPH, represents one of the main thiol-dependent electron donor systems and plays critical roles in the regulation of the cellular redox environment [49]. Although the reduction of oxidized PTEN appears to be dominantly mediated by Trx, it has been reported that $\operatorname{Trx} 1$ inhibits its phosphatase activity by binding in a redox dependent manner to PTEN through disulfide bond formation [45]. Moreover, knocking out of thioredoxininteracting protein, an inhibitor of Trx NADPH-dependent reduction of PTEN, causes accumulation of oxidized PTEN and elevated Akt phosphorylation [50]. We find that there is a significantly augmented formation of Trxl-PTEN complexes in tumor cells derived from adiponectin haplodeficient PyVT mice, possibly due to elevated TrxRl and Trxl activities (Figure 9A). Adiponectin treatment decreases TrxRl promoter-mediated transcription and its mRNA levels, which are highly upregulated in adiponectin haplodeficient tumors (Figure 9D). These results suggest that adiponectin might regulate PTEN activities through

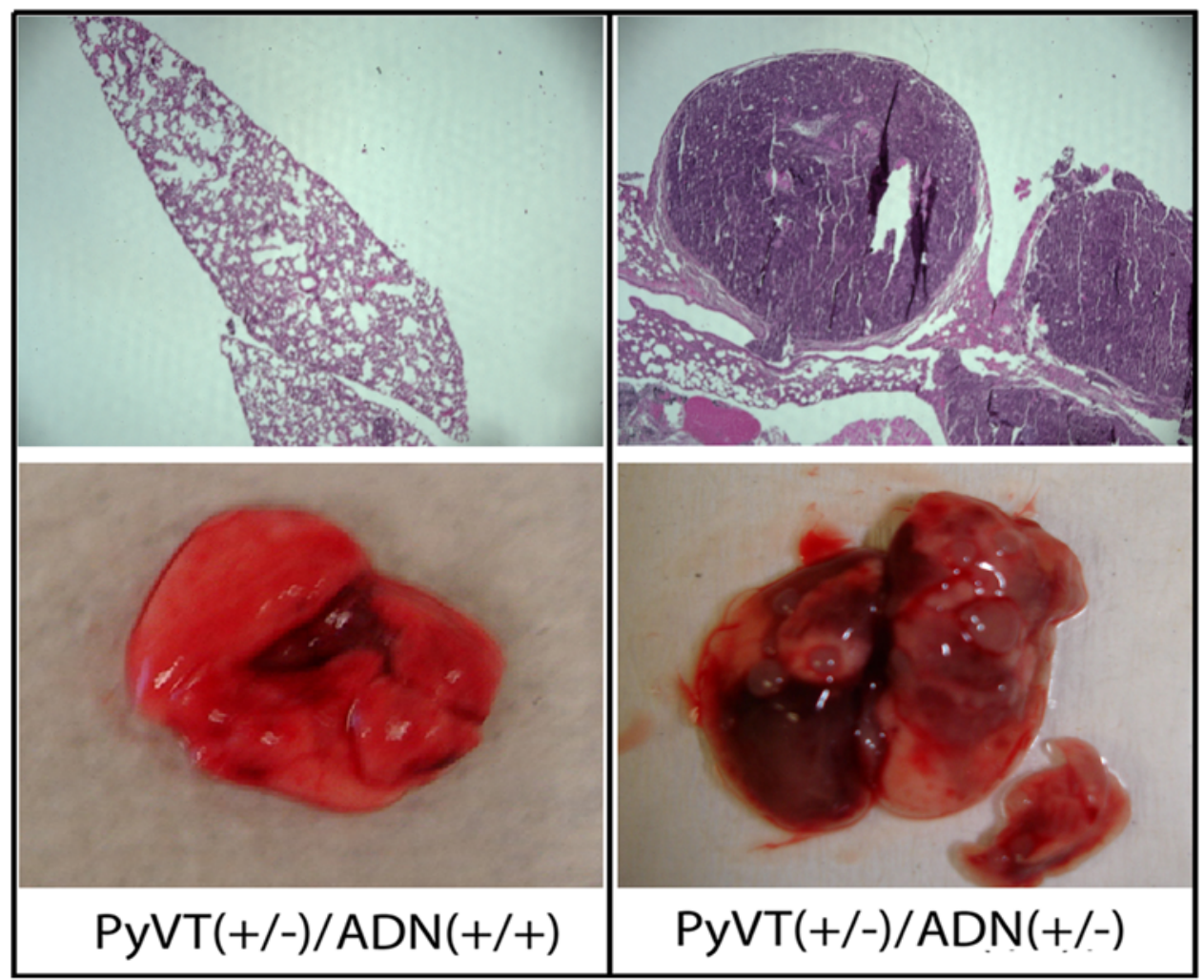

Figure 6. Tumor cells derived from male $P y V T(+/-) / A D N(+/-)$ mice show increased metastatic capacities in nude mice comparing with those of PyVT $(+/-) / A D N(+/+)$ mice. Both hematoxylin and eosin staining (upper panel) and the morphological evaluations (bottom panel) were performed to evaluate metastasis of the lung tissues. doi:10.1371/journal.pone.0004968.g006 

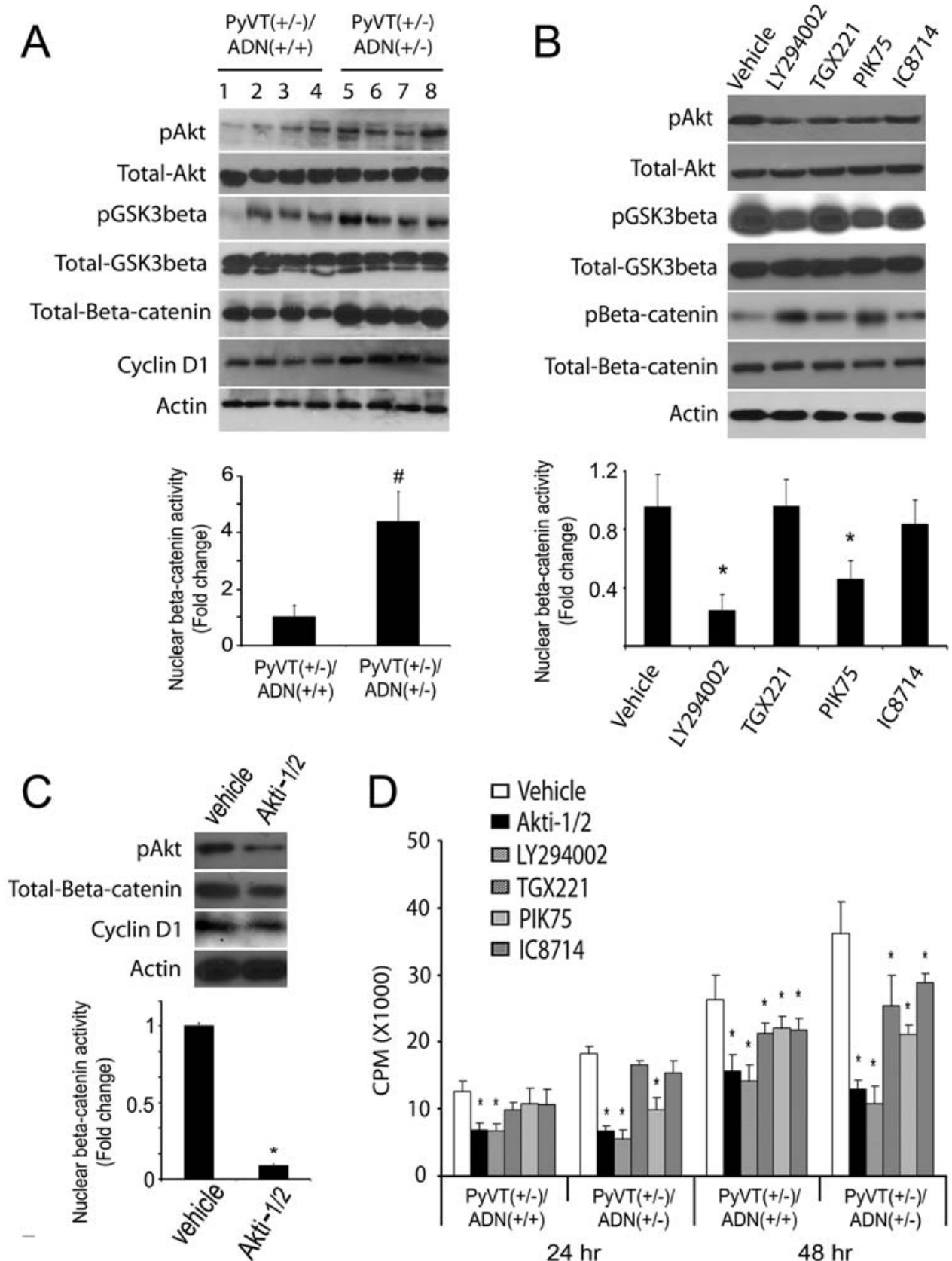

Figure 7. Hyperactivation of Akt/GSK3beta/beta-catenin signaling in adiponectin haplodeficient tumors. $A$, Components of the PI3K/ Akt/beta-catenin axis were characterized in the tumor cell lysates by Western blotting (upper panel) and nuclear beta-catenin activities analyzed using a TOPflash/FOPflash luciferase reporter assay (bottom panel). Results were expressed as fold changes relative to the values of samples derived from PyVT(+/-)/ADN(+/+) cells. \#, P<0.01 vs PyVT(+/-)/ADN(+/+) group $(\mathrm{n}=6)$. B, Various pharmacological inhibitors, including LY294002 for PI3K, PIK-75 for p110alpha, TGX221 for p110beta and IC8714 for p110delta, were used for the treatment of PyVT(+/-)/ADN $(+/-)$ tumor cells at the concentration of $10^{-6} \mathrm{M}$. The phosphorylations of Akt (pAkt), GSK3beta (pGSK3beta), and beta-catenin (pBeta-catenin), as well as their total levels in the cell samples treated with each specific inhibitor for $30 \mathrm{~min}$ were analyzed by Western Blotting (upper panel). After $24 \mathrm{hr}$ incubation, the nuclear beta-catenin activities were evaluated using the TOPflash/FOPflash reporter assay (bottom panel). ${ }^{*}, \mathrm{P}<0.01$ vs vehicle $(\mathrm{n}=4)$. $C$, Primary tumor cells isolated from PyVT(+/-)/ADN(+/-) mice were cultured and treated without (vehicle) or with $10^{-6} \mathrm{M}$ of specific inhibitor of Akt-1/Akt-2 isoforms (Akti1/2) for $24 \mathrm{hr}$. Protein levels of phosphorylated Akt (pAkt), beta-catenin, and cyclinD1 in the cell lysates were analyzed by Western Blotting (upper panel) and the nuclear beta-catenin activities measured using a TOPflash/FOPflash luciferase reporter system (bottom panel). ${ }^{*}, \mathrm{P}<0.01$ vs vehicle control $(n=3)$. D, Evaluation of the effects of various inhibitors on cell proliferation by $\left[{ }^{3} \mathrm{H}\right]$-thymidine incorporation assay. CPM, counts per minute. * , $P<0.01$ vs vehicle in each treatment group $(n=5)$. Results were derived from three independent experiments. doi:10.1371/journal.pone.0004968.g007

Trx/TrxR redox system, and an altered Trx/TrxR redox balance could play important roles in promoting tumorigenesis in $P y V T+1$ $-) / A D N(+/-)$ mice.
In this study, we have shown that inhibition of both PI3K and Akt results in a reduced nuclear beta-catenin activities and protein stabilities, supporting the involvement of PI3K/Akt pathway in the 


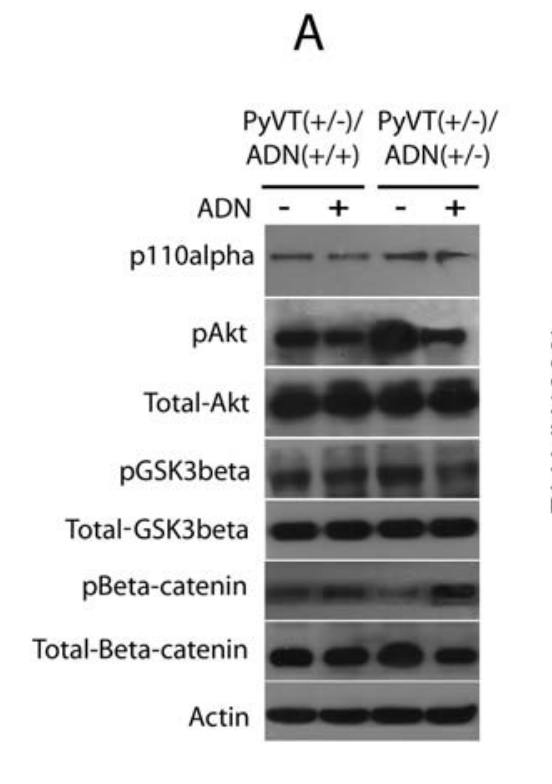

B
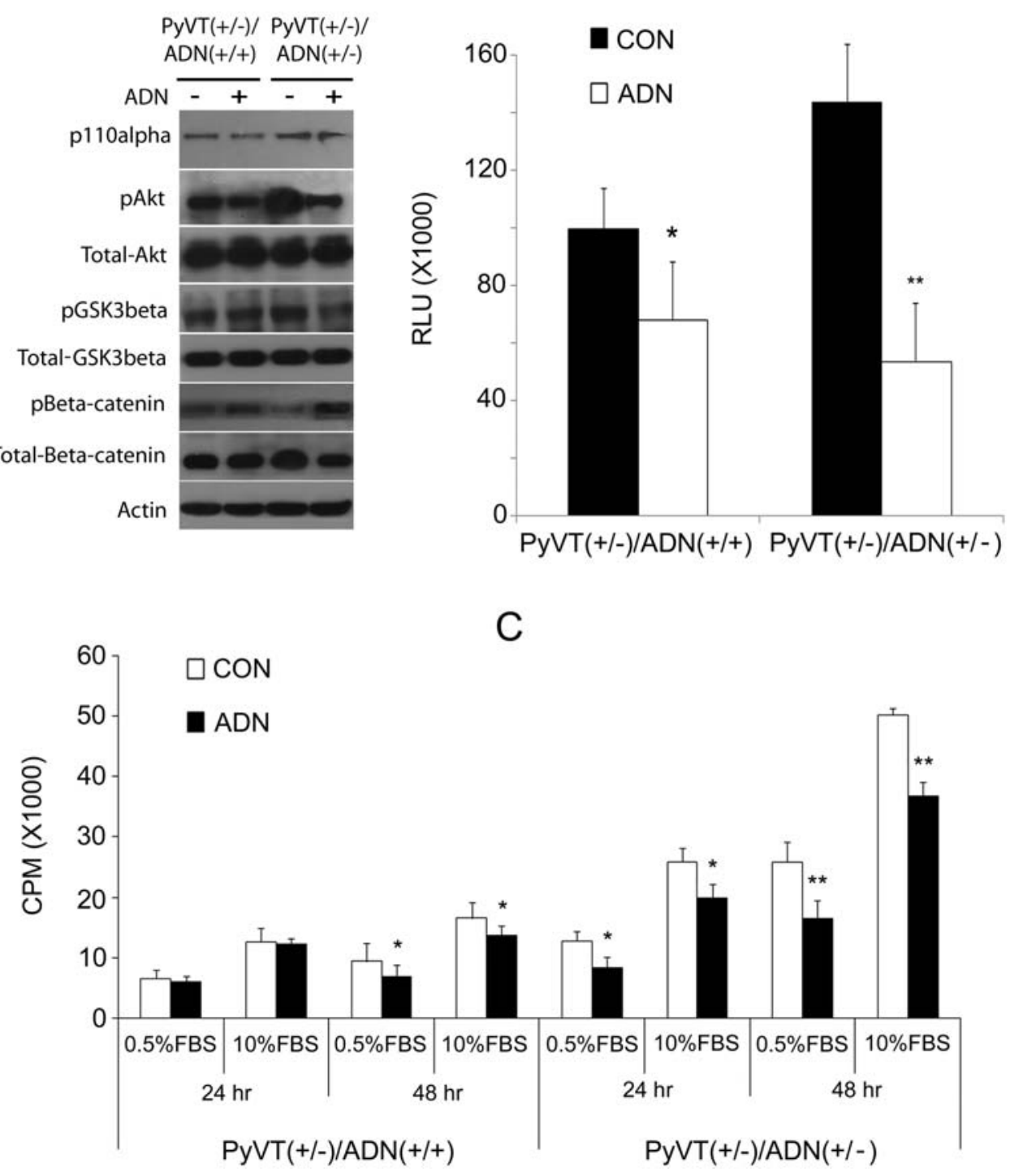

Figure 8. Tumor cells derived from $P y V T(+/-) / A D N(+/-)$ mice showed increased sensitivity to adiponectin-mediated inhibition of Akt/GSK3beta/beta-catenin signaling and cell proliferation. Tumor cells isolated from both PyVT(+/-)/ADN(+/+) and PyVT(+/-)/ADN(+/-) mice were pre-treated with $15 \mu \mathrm{g} / \mathrm{ml}$ of adiponectin for $24 \mathrm{hr}$ in $0.5 \%$ FBS DMEM. The serum-stimulated phosphorylation changes of Akt, GSK3beta and beta-catenin were analyzed by Western Blotting $(\mathrm{A})$ as described previously [28]. The nuclear beta-catenin activities were assayed using the TOPflash/FOPflash reporter assay (B). Cell proliferation was evaluated for both types of tumor cells under the indicated treatment conditions using ${ }^{3} \mathrm{H}$ thymidine incorporation assay (C). ${ }^{*}, \mathrm{P}<0.05$ and ${ }^{* *}, \mathrm{P}<0.01$ vs corresponding vehicle control $(\mathrm{n}=3$, from three independent experiments). doi:10.1371/journal.pone.0004968.g008

hyper-activation of beta-catenin signalling associated with adiponectin haplodeficient tumors (Figure 7). Notably, the cross-talks between PI3K/Akt and the canonical Wnt/beta-catenin signaling pathways have been demonstrated by a number of studies from independent groups (23). Overexpression of PTEN inhibits Wnt-1 induced beta-catenin stabilization and mammary tumorigenesis in mice [51]. PI3K/Akt pathway is involved in Wnt3a-induced proliferation and beta-catenin nuclear accumulation in NIH3T3 cells [52]. In HT29 colorectal adenocarcinoma cells, inhibition of PI3K was accompanied by a considerably reduced expression level of beta-catenin [53]. The linkage between Wnts and PI3K/Akt signalling have also been found in the regulation of bone mass, osteoblast progenitor proliferation, differentiation and osteoblast apoptosis, as well as cardiomyogenesis [54]. The protein levels of p110alpha subunits are elevated in tumor cells isolated from adiponectin haplodeficient PyVT mice. However, adiponectin treatment has no effects on pl10alpha, despite that it can inhibit Akt phosphorylation and nuclear beta-catenin activities (Figure 7), suggesting that the inhibitory effects of this hormone is downstream of PI3K and upstream of Akt, possibly through modulating PTEN's activities.

Insufficiency in adiponectin production might promote mammary tumor formation from distinct type of cells, as suggested by the consistent morphological and gene expression differences between tumors derived from $P y V T(+/-) / A D N(+/+)$ and PyVT(+/-)/ADN(+/-) mice (Figure 3). Adiponectin haplodeficient tumor is more related to a basal-like subtype, which is characterized by high proliferative activity and unfavorable 
A

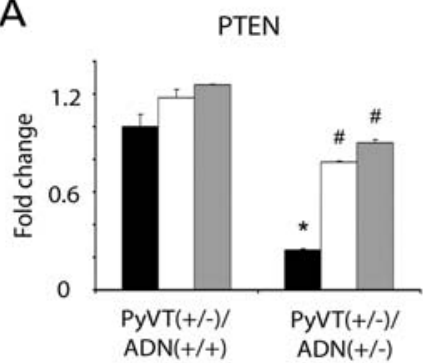

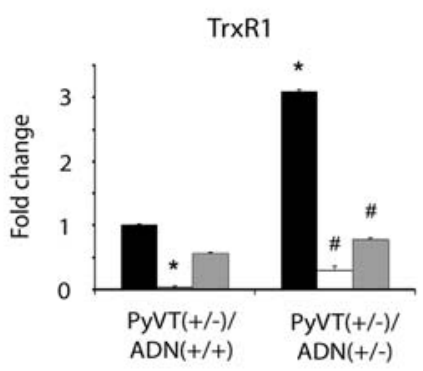

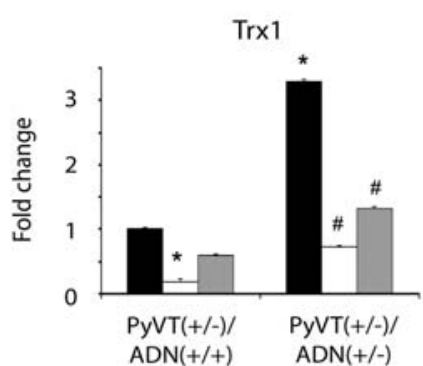

B

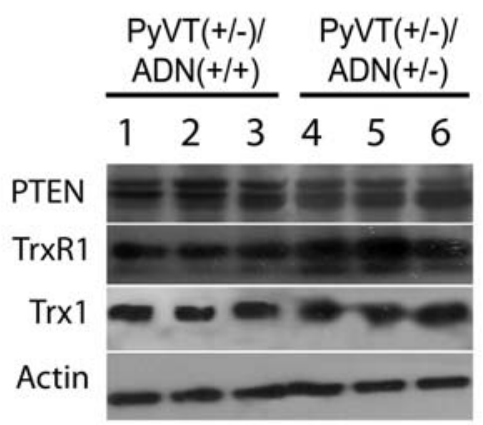

D

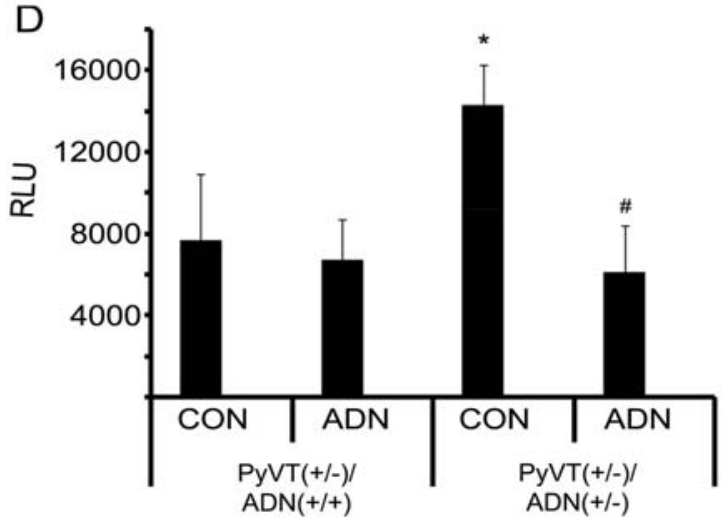

C

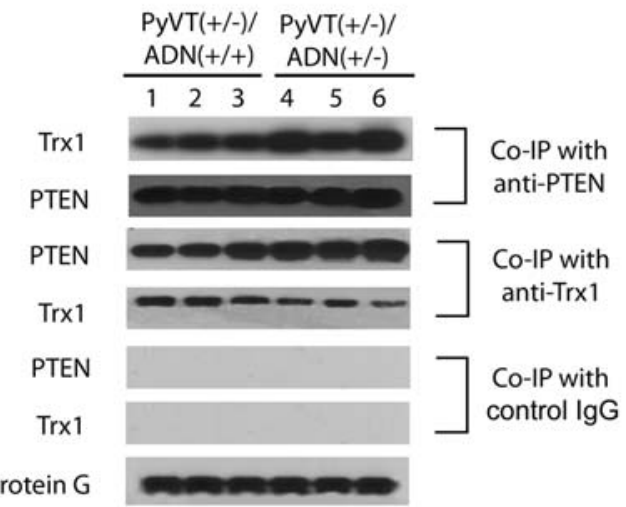

Figure 9. Inactivation of PTEN was at least partially caused by the augmented Trx1/TrxR1 redox activities in $P y V T(+/-) / A D N(+/-)$ tumor cells. $A$, activities of PTEN, TrxR1 and Trx were evaluated in the lysates derived from PyVT(+/-)/ADN(+/+) and PyVT(+/-)/ADN(+/-) tumor cells using colorimetric assays. Briefly, cells were treated with vehicle control (CON), $10 \mu \mathrm{M}$ curcumin (CUR) or $15 \mu \mathrm{g} / \mathrm{ml}$ adiponectin (ADN) for $24 \mathrm{hrs}$. Immunoprecipitation and phosphatase assay were performed as described in Methods. Results were expressed as fold changes relative to the enzyme activities in PyVT(+/-)/ADN(+/+) tumor cells treated with vehicle control. $B$, total protein levels of PTEN, TrxR1 and Trx1 in cell lysates from PyVT(+/-)/ADN(+/+) and PyVT(+/-)/ADN(+/-) tumors were analyzed by Western Blotting. $C$, co-immunoprecipitations were performed with the specific antibodies against PTEN or Trx 1 in both PyVT(+/-)/ADN(+/+) and PyVT(+/-)/ADN(+/-) tumor cell lysates. The immune-complexes were analyzed by SDS-PAGE and Western Blotting using antibodies as indicated. $D$, intrinsic transcriptional activities of TrxR1 promoter (left panel) and the mRNA levels of TrxR1 and Trx1 (right panel) were evaluated in PyVT(+/-)/ADN(+/+) and PyVT(+/-)/ADN(+/-) tumor cells treated without (CON) or with adiponectin (ADN, $15 \mu \mathrm{g} / \mathrm{ml}$ ) using TrxR1 reporter assay (left panel) and quantitative RT-PCR respectively (right panel). ${ }^{*}, \mathrm{P}<0.05 \mathrm{vs} P y V T(+/-) /$ $A D N(+/+)$ cell control; \#, $\mathrm{P}<0.05$ vs PyVT(+/-)/ADN (+/-) cell control $(\mathrm{n}=3$, from three independent experiments).

doi:10.1371/journal.pone.0004968.g009

prognosis. The origin of this subtype tumor is unclear, but suggested to be the basal/myoepithelial cells, derived from epithelial-to-mesenchymal transition as a result of dedifferentiation, or from stem cells [43]. It will be interesting to investigate which types of tumor cell transformation could be facilitated by the altered microenvironment associated with adiponectin haploinsufficiency. It has long been noticed that cancer cells exhibit increased glycolysis for ATP production due, in part, to respiration injury (the Warburg effect). The increase in $\mathrm{NADH}$ caused by respiratory deficiency inactivates PTEN through a redox modification mechanism, leading to Akt activation. Our group has recently reported that adiponectin deficiency leads to dysregulated mitochondrial functions, which result in decreased activities of the respiratory chain and subsequent accumulation of reactive oxygen species [55]. We have also found that adiponectin can modulate redox-regulated transcription factor Spl activities [56]. Interestingly, the expression of both Trx 1 and TrxRl can be regulated by Spl [57]. Whether these mechanisms contribute to the dysregulated Trx/TrxR redox system in adiponectin insufficiency-related carcinogenesis are currently under investigation in our laboratory. Nevertheless, these findings might provide a novel mechanistic insight to explain how metabolic alteration in adiponectin haplodeficient tumor may gain a survival advantage. 


\section{Materials and Methods}

\section{Materials}

Antibodies against PI3K p110-alpha (\#4255), PI3K p85 (\#4292), phospho-Akt (Ser473) (\#9271), Akt (\#9272), GSK3beta (\#9315), phospho-GSK3beta (Ser9) (\#9336) and phospho-betacatenin (Ser33/37/Thr41) (\#9561) were obtained from Cell Signaling Biotechnology (Beverly, MA). Anti-Trx1 (sc-20146), anti-TrxR1 (sc-28321), and anti-beta actin (sc-1615) antibodies were from Santa Cruz Biotechnology (Santa Cruz, CA). AntiPTEN (MAB4037) was from Chemicon International, Inc. (Temecula, CA), anti-Cyclin D1 (CC12) was from CalBiochemNovachem Crop. (San Diego, CA), and sheep anti-beta-catenin was from Symansis (Auckland, New Zealand). Pharmacological inhibitors, including Akt-1/2 inhibitor, PI3K p110alpha inhibitor PIK-75, PI3K p110beta inhibitor TGX221, and PI3K p110delta inhibitor IC87114 were provided by Dr Peter R. Shepherd [34,35]. The general PI3K inhibitor, LY294002, was from Cell Signaling Biotechnology. ImProm-II ${ }^{\mathrm{TM}}$ Reverse Transcription System and Bright-GloTM luciferase assay system were from Promega (Madison, WI). TOP/FOPflash (T-cell factor-lymphoid enhancer factor-1 (TCF-LEF) reporter plasmid) was from Upstate (Lake Plasid, NY). pGL-TrxR1 reporter plasmid was generated by cloning the proximal promoter of the human TrxRl gene using the GenomeWalker kit from Clontech (Palo Alto, CA). The human TrxRl and Trxl were purchased from Sigma. The rat TrxRl was purified from rat liver according to published procedure [36] and the purity confirmed by mass spectrometry analysis. Unless specified, all chemicals were obtained from SigmaAldrich Co. (St Louis, MO). Recombinant full length adiponectin (ADN) was produced as we described previously [28].

\section{Establishment of the MMTV-PyVT transgenic mice haplodeficient in adiponectin expression}

FVB/N-Tg(MMTV-PyVT)634Mul/J transgenic mice were obtained from the Jackson Laboratory (Bar Harbor, Maine) [37]. Since the female PyVT transgenic mice were defective in litter delivery and lactation, all breedings were carried out using male PyVT transgenic mice. The male heterozygote PyVT(+/-) mice were cross-bred with female adiponectin knockout mice [38] and back-crossed for at least 12 generations to obtain mice with reduced adiponectin expression in both $\mathrm{C} 57 \mathrm{BL} / 6 \mathrm{~J}$ and $\mathrm{FVB} / \mathrm{N}$ backgrounds. The genotype was verified by PCR analysis of their genomic DNA using primers listed in Table 3. In addition, serum adiponectin levels were monitored using an in-house ELISA, with the standard curve generated from known concentrations of recombinant adiponectin. Note that mice with the genotype of PyVT(+/-)/ADN (-/-) (transgenic PyVT with adiponectin null alleles) could not be found in all generations of alive litters, which included over 800 mice. On the other hand, their embryos were found to be dead at the early stage of foetal development. As a consequence, the sizes of litters with abnormal adiponectin expressions (3-5) were consistently smaller when compared to those of control PyVT breeding pairs (8-10). Therefore, the PyVT transgenic mice with adiponectin deficiency were referred to those with $\operatorname{Py} T(+/-) / A D \mathcal{N}(+/-)$ genotypes in this study. The circulating levels of adiponectin in $P y V T(+/-) / A D N(+/-)$ $\mathrm{FVB} / \mathrm{N}$ and $\mathrm{C} 57 \mathrm{BL} / 6 \mathrm{~J}$ mice range from $3-15 \mu \mathrm{g} / \mathrm{ml}$ and $0.2-$ $5 \mu \mathrm{g} / \mathrm{ml}$ respectively, whereas $P y V T(+/-) / A D \mathcal{N}(+/+)$ mice in both FVB/N and C57BL/6J background have a much higher adiponectin level of over $20 \mu \mathrm{g} / \mathrm{ml}$ and $10 \mu \mathrm{g} / \mathrm{ml}$ respectively, with the median values increased by $4-5$ folds. Tumor development was closely monitored every 2-3 days. Tumor latency was recorded as the age of mice when palpable tumors were first detected in at least one of the ten mammary fat pads. Tumor sizes were measured using digital vernier calipers and tumor volume calculated using the formula [sagittal dimension $(\mathrm{mm}) \times\left(\operatorname{cross}\right.$ dimension $\left.(\mathrm{mm})^{2}\right] / 2$ and expressed in $\mathrm{mm}^{3}$. All animal experimental protocols were approved by the Animal Ethics Committee at the University of Hong Kong and their care was in accord with the institution guidelines.

\section{Sandwich ELISA for murine adiponectin}

The anti-murine adiponectin monoclonal antibody was biotinylated with a kit from Pierce, and free biotin was removed by dialysis. The polyclonal anti-murine adiponectin antibody was diluted to a concentration of $2 \mu \mathrm{g} / \mathrm{ml}$, added to each well of a microtiter plate, and incubated overnight at $4{ }^{\circ} \mathrm{C}$. The coated plate was washed 3 times with PBS containing $1 \%$ bovine serum albumin and blocked with $100 \mu \mathrm{l}$ of PBS containing $1 \%$ bovine serum albumin and $0.05 \%$ Tween for $2 \mathrm{~h}$. Mouse serum was diluted 1:10000, and $100 \mu \mathrm{l}$ of the diluted samples were applied to each well along with the standard, incubated at $37{ }^{\circ} \mathrm{C}$ for $1 \mathrm{~h}$, washed 3 times with PBS-Tween, and then incubated with $100 \mu \mathrm{l}$ of the biotinylated monoclonal antibody $(2 \mu \mathrm{g} / \mathrm{ml})$ for another $2 \mathrm{~h}$. After washing 3 times, the wells were incubated with streptavidin-conjugated horseradish peroxidase for $60 \mathrm{~min}$ and subsequently reacted with tetramethylbenzidine reagent for $15 \mathrm{~min}$. $100 \mu \mathrm{l}$ of $2 \mathrm{M} \mathrm{H}_{2} \mathrm{SO}_{4}$ was added to each well to stop the reaction, and the absorbance at $450 \mathrm{~nm}$ was measured. The intra- and interassay coefficients of variance were determined by measuring five plasma samples in a total of six independent assays with duplicate determinations.

Primary tumor cell isolation, culture and re-implantation

Primary cell isolation was performed as described previously with slight modifications [39]. Briefly, aseptically collected tumors from PyVT mice were mechanically minced, passaged through a $100-\mu \mathrm{m}$ sterile nylon cell strainer (BD Falcon) and suspended in serum-free high glucose DMEM. Cells were further dissociated by serial passaging through a syringe with 25-gauge needles. After brief centrifugation at 1,000 r.p.m for 5 minutes to remove dead cell debris and the low-density stromal cells, the cell pellets were resuspended for viable cell counting using $0.4 \%$ trypan blue. $10^{6}$ of isolated primary tumor cells were implanted into the third right mammary fat pad of female athymic nu/nu mice (4-6 weeks) by intraductal injection. Tumor development was monitored every 34 days using caliper measurements (in millimeters) in two perpendicular dimensions (length and width). Tumor volumes were calculated as described above.

\section{Co-immunoprecipitation and Western Blotting}

Isolated tumor tissues were homogenized in RIPA buffer [50 mM Tris-HCl, pH 7.4; 1 mM EDTA; $150 \mathrm{mM} \mathrm{NaCl;} 1 \%$ Nonidel P40; $1 \%$ Triton X-100; 0.5\% deoxycholic acid sodium salt; $1 \mathrm{mM} \mathrm{NaF}$; $1 \mathrm{mM}$ sodium orthovanadate; and complete protease inhibitor cocktail (Roche Applied Science, IN)] on ice and centrifuged for $5 \mathrm{~min}$ at 14,000 r.p.m to remove large debris. Protein concentration of the supernatant was determined by a BCA Protein Reagent Kit (Pierce Biotechnology, Rockford, IL). Five hundred micrograms of the total cell lysates were firstly incubated with rabbit IgG for 30 minutes, pre-cleared with $50 \mu \mathrm{l}$ of protein G-Sepharose beads (Pierce Biotechnology, Rockford, IL), and then incubated with two micrograms of either Anti-Trxl or Anti-PTEN antibody overnight at $4^{\circ} \mathrm{C}$. $50 \mu \mathrm{l}$ of protein GSepharose beads was added and incubated for $2 \mathrm{hrs}$ at $4^{\circ} \mathrm{C}$. Beads bound with immune complexes were collected by centrifugation and washed twice prior to elution into $90 \mu \mathrm{l}$ of buffer containing 
Table 3. List of primers used for genotyping.

\begin{tabular}{|c|c|c|c|c|}
\hline Primer name & NCBI GeneBank accession IDs & Sequence range & $\begin{array}{l}\text { Product } \\
\text { size (bp) }\end{array}$ & Primer sequences \\
\hline \multirow[t]{2}{*}{ AdipoWT } & NT_039624 & 11673-12146 & 473 & (F) 5'- CCA GAG AAC AAC GAA CAA GGA- 3' \\
\hline & & & & (R) $5^{\prime}-$ CGA ATG GGT ACA TTG GGA AC- $3^{\prime}$ \\
\hline \multirow[t]{2}{*}{$\mathrm{Neo}$} & $\begin{array}{l}\text { User_PGKneobpA Sequence sequence } 4575 \text { bp DNA } \\
\text { circular SYN 08/24/2007 }\end{array}$ & $2950-3101$ & 171 & (F) $5^{\prime}$ - TGA ATG AAC TGC AGG ACG AG- $3^{\prime}$ \\
\hline & & & & (R) 5' - ATA CTT TCT CGG CAG GAG CA- 3' \\
\hline \multirow[t]{2}{*}{ MMTV/PyVT } & J02288 & $881-1437$ & 556 & (F) 5'- GGA AGC AAG TAC TTC ACA AGG G- 3' \\
\hline & & & & (R) 5'- GGA AAG TCA CTA GGA GCA GGG- 3' \\
\hline \multirow[t]{2}{*}{ Tcrd } & NG_007044 & $1715433-1715638$ & 206 & (F) 5'- CAA ATG TTG CTT GTC TGG TG- 3' \\
\hline & & & & (R)5' GTC AGT CGA GTG CAC AGT Tा- 3' \\
\hline
\end{tabular}

0.2 M Glycine-HCl, pH 2.5, which was neutralized with $10 \mu \mathrm{l}$ of neutralization buffer (1 M Tris-HCl, $\mathrm{pH}$ 9.0). The elutants were subjected to $15 \%$ SDS-PAGE and Western blotting analysis, or enzyme activity measurement as described below.

For Western Blotting, fifty micrograms of proteins derived from cell or tissue lysates were separated by SDS-PAGE and transferred to polyvinylidene difluoride membranes. Following blocking, membranes were probed with various primary antibodies to determine different levels of protein expressions. Immunoreactive antibody-antigen complexes were visualized with the enhanced chemiluminescence reagents from GE Healthcare (Uppsala, Sweden).

\section{$\left[{ }^{3} \mathrm{H}\right]$-thymidine incorporation assay for cell proliferation measurement}

$5 \times 10^{4}$ of isolated primary tumor cells were seeded into each of the 24-well culture plate and allowed a period of at least 24 hours for cell settlement and attachment. After being treated under different conditions, $1 \mu \mathrm{Ci} / \mathrm{ml}$ of $\left[{ }^{3} \mathrm{H}\right.$-methyl $]$ thymidine was added into each well for 6 hours of incorporation. At the end of experiment, the culture media were removed and cells washed twice with cold PBS. DNA was precipitated with $0.5 \%$ trichloroacetic acid for $30 \mathrm{~min}$. Air-dried precipitates were then solubilized with $0.2 \mathrm{~mol} / \mathrm{l} \mathrm{NaOH}$, neutralized with $0.2 \mathrm{~mol} / \mathrm{l}$ $\mathrm{HCl}$, and incorporated $\left[{ }^{3} \mathrm{H}\right]$-thymidine was quantified with a liquid scintillation counter (Backman LS6500).

\section{Quantitative RT-PCR}

Total RNA was isolated from primary tumor cells and used for the synthesis of cDNA. Quantitative RT-PCR was performed using SYBR ${ }^{\circledR}$ GreenER ${ }^{\mathrm{TM}}$ qPCR Supermix (Invitrogen, Carlsbad, CA). The reactions were carried out on a 7000 Sequence Detection System (Applied Biosystems, Foster City, CA). Quantification was achieved using $\mathrm{Ct}$ values that were normalized with 18S RNA as internal control. The primers were listed in Table 4.

\section{Beta-catenin/T-cell factor-lymphoid enhancer factor-1 (TCF-LEF) and thioredoxin reductase 1 (TrxR1) \\ transcription reporter assay}

Nuclear activities of endogenous beta-catenin were analyzed by the TOPflash/FOPflash reporter system as described previously [28]. To normalize transfection efficiency in the reporter assays, cells were cotransfected with pRL-TK plasmid, which contains a functional Renilla luciferase gene cloned downstream of a herpes simplex virus thymidine kinase promoter (Promega, Madison, WI).
The luciferase reporter containing a human thioredoxin reductase promoter region (from $-386 \mathrm{bp}$ to $+218 \mathrm{bp}$, pGL3-TR) was constructed into a firefly-luciferase pGL3-basic Vector (Promega, Madison, WI). The assay was carried out as described above with the original unmodified pGL3-basic vector as a negative control. Luminescence was measured using a Bright-Glo ${ }^{\text {TM }}$ Luciferase Assay System (Promega, Madison, WI) on Lumat LB9507, and normalized to control Renilla luciferase signal. Luciferase activity was calculated against the negative control signals and fold differences were compared among groups in separate assays.

\section{Measurement of PTEN lipid phosphatase activities}

The lipid phosphatase activity of PTEN was measured as described previously with slight modifications [40]. Phosphatase reactions were performed in $25 \mu \mathrm{l}$ assay buffer $(100 \mathrm{mM}$ Tris-HCl pH 8, $10 \mathrm{mM}$ DTT, and $200 \mu \mathrm{M}$ water-soluble diC8-PIP3) with $25 \mu \mathrm{l}$ sample. PTEN proteins immunoprecipitated on protein $\mathrm{G}$ Sepharose beads (Pierce Biotechnology, Rockford, IL) were washed twice in a low stringency buffer (20 mM HEPES, pH 7.7, $50 \mathrm{mM}$ $\mathrm{NaCl}, 0.1 \mathrm{mM}$ EDTA and $2.5 \mathrm{mM} \mathrm{MgCl}_{2}$ ) and once in the phosphatase assay buffer lacking PIP3. Reactions were done in a 96well plate with an incubation period of 40 minutes at $37^{\circ} \mathrm{C}$. The release of phosphate from the substrate was measured in a colorimetric assay by using the Biomol Green Reagent in accordance with the instructions of the manufacturer. The absorbance at $620 \mathrm{~nm}$ was measured with a $\mu$ Quant MQX200 microplate reader (Biotek Instruments, Inc., Highland Park, VT). A standard curve was performed in each assay, and the amount of free phosphate was calculated from the standard curve line-fit data.

\section{Measurement of TrxR1 and Trx1 activities}

The assays for measuring the activities of TrxR and Trx were performed in 96-well plates using an insulin reduction endpoint assay as described previously [41] with slight modification. For determination of TrxR1 activity, $25 \mu \mathrm{g}$ of the primary tumor lysates were mixed thoroughly with a $50 \mu \mathrm{l}$ reaction buffer containing $55 \mathrm{mM}$ HEPES, pH 7.6, $0.02 \mathrm{mM}$ insulin, 0.4 mM NADPH, 2 mMEDTA and $2 \mu \mathrm{M}$ human Trx 1 in the $\mu$ Quant MQX200 microplate reader (Biotek Instruments, Inc). Reaction solutions without human Trx 1 were used as the control. After performing a 20-min incubation at $37^{\circ} \mathrm{C}, 200 \mu \mathrm{l}$ of $1 \mathrm{mM}$ DTNB in $6 \mathrm{M}$ guanidine hydrochloride solution was added to stop the reaction. The free thiols of the reduced insulin were determined by DTNB reduction, and the activity of TrxR was represented as the absorbance at wavelength $412 \mathrm{~nm}$, where 1 mole of NADPH reduced 1 mole of disulfide, giving rise to 2 
Table 4. List of primers used for real time quantitative PCR analysis.

\begin{tabular}{|c|c|c|c|c|c|}
\hline Gene name & $\begin{array}{l}\text { Gene } \\
\text { symbol }\end{array}$ & $\begin{array}{l}\text { Accession } \\
\text { IDs }\end{array}$ & $\begin{array}{l}\text { Sequence } \\
\text { range }\end{array}$ & $\begin{array}{l}\text { Product size } \\
\text { (bp) }\end{array}$ & Primer sequences \\
\hline \multirow[t]{2}{*}{ Forkhead box A1 } & FOXA1 & NM_008259 & $456-588$ & 133 & (F) 5'-GAA GGG CTC CTG TGC TAG Tा-3' \\
\hline & & & & & (R) 5'-AGG ACA TGT TGA AGG AAG CC-3' \\
\hline \multirow[t]{2}{*}{ Protein tyrosine phosphatase $4 \mathrm{a} 2$} & PTP4A2 & NM_008974 & $427-598$ & 172 & (F) 5'-GAA GGG CTC CTG TGC TAG חT-3' \\
\hline & & & & & (R) 5'-TGC CCA TTG GTA TCT CTG AA-3' \\
\hline \multirow[t]{2}{*}{ c-mer proto-oncogene tyrosine kinase } & MERKT & NM_008587 & $1944-2127$ & 185 & (F) 5'-AAG CAG CAT GCA TGA AAG AC-3' \\
\hline & & & & & (R) 5'-TGC AGG TGA ATG TAC TTG GG-3' \\
\hline \multirow[t]{2}{*}{ Estrogen receptor 1 (alpha) } & ESR1 & NM_007956 & $1560-1752$ & 193 & (F) 5'-CCG GAG TGT ACA CGT TTC TG-3' \\
\hline & & & & & (R) 5'-TTG TTA CTC ATG TGC CGG AT-3' \\
\hline \multirow{2}{*}{$\begin{array}{l}\text { ATP synthase, } \mathrm{H}+\text { transporting, mitochondrial } \\
\text { F0 complex, subunit c }\end{array}$} & ATP5G & NM_007506 & $167-223$ & 57 & (F) $5^{\prime}$-GGG AAT TCC AGA CCA GTG TC-3' \\
\hline & & & & & (R) 5'-TTG AGA GAT GGG TTC CTG GC-3' \\
\hline \multirow[t]{2}{*}{ Cyclin E1 } & CCNE1 & NM_007633 & $160-330$ & 171 & (F) 5'-ACA GCT TCG GGT CTG AGT TC-3' \\
\hline & & & & & (R) 5'-GGC AAT TTC TTC ATC TGG GT-3' \\
\hline \multirow[t]{2}{*}{ Peroxiredoxin 4} & PREDX4 & NM_016764 & 716-883 & 118 & (F) $5^{\prime}$-CGA TGA CAA AGG AGT CCT GA-3' \\
\hline & & & & & (R) 5'-GCT GGA TCT GGG ATT ATT GT-3' \\
\hline \multirow[t]{2}{*}{ Keratin 17} & KRT17 & NM_010663 & $679-851$ & 173 & (F) 5'-AAG AAG AAC CAC GAG GAG GA-3' \\
\hline & & & & & (R) 5'-AAG AAC CAG TCT TCG GCA TC-3' \\
\hline \multirow[t]{2}{*}{ Keratin 5} & KRT5 & NM_027011 & $1005-1170$ & 166 & (F) 5'-GCA GAC ACA CGT CTC TGA CA-3' \\
\hline & & & & & (R) 5'-TTG CAG CTC CTC ATA CTT GG-3' \\
\hline \multirow[t]{2}{*}{ Milk fat globule-EGF factor 8 protein } & MFGE8 & NM_001045489 & $278-444$ & 167 & (F) 5'-AGA CTG AGA GAG GAC CAT GC-3' \\
\hline & & & & & (R) 5'-CAT GCC CAG CTG TGT AGA AC-3' \\
\hline \multirow[t]{2}{*}{ Frizzled homolog 7} & FZD7 & NM_008057 & $1477-1631$ & 155 & (F) $5^{\prime}$-TTC CTA GGT GAG CGT GAC TG-3' \\
\hline & & & & & (R) 5'-TAG GTG AGC ACC GTG AAG AG-3' \\
\hline \multirow[t]{2}{*}{ Chemokine (C-X-C motif) ligand 1} & CXCL1 & NM_008176 & 179-352 & 174 & (F) 5'-ACC CAA ACC GAA GTC ATA GC-3' \\
\hline & & & & & (R) 5'-GTT GTC AGA AGC CAG CGT T-3' \\
\hline \multirow[t]{2}{*}{ v-erb-b2 erythroblastic leukemia viral oncogene homolog 2} & ERBB2 & NM_001003817 & $2980-3162$ & 183 & (F) 5'-ATT TGC TGG AGA AGG GAG AA-3' \\
\hline & & & & & (R) 5'-AGT CCT CGT TCT GGA TGA CC-3' \\
\hline \multirow[t]{2}{*}{ Mediator complex subunit 1} & MED1 & NM_013634 & $1459-1623$ & 165 & (F) $5^{\prime}$-CAG ACC TTG GAG TGA AAC CA-3' \\
\hline & & & & & (R) 5'-GAG CCC AGT CCA TTC TGT CT-3' \\
\hline \multirow[t]{2}{*}{ Acyl-CoA synthase long-chain family member 1} & ACSL1 & NM_007981 & $1586-1759$ & 174 & (F) $5^{\prime}$-CTA TGA AGG CTA CGG ACA GA-3' \\
\hline & & & & & (R) 5'-CCT TTC ACA CAC ACC TCA CC-3' \\
\hline \multirow{2}{*}{$\begin{array}{l}\text { Phosphatidylinositol 3-kinase, regulatory subunit, } \\
\text { polypeptide } 1 \text { (p85 alpha) }\end{array}$} & PIK3R1 & NM_001077495 & $1906-2080$ & 175 & (F) 5'-TCC AAA TAC CAG CAG GAT CA-3' \\
\hline & & & & & (R) 5'-ATG CTT CGA TAG CCG TTC TT-3' \\
\hline \multirow[t]{2}{*}{ Thioredoxin reductase 1} & TXNRD1 & NM_00142523 & $1587-1763$ & 177 & (F) 5'-TTG GAA TAT GGC TGT TGT GG-3' \\
\hline & & & & & (R) 5'-CAC GAC ACG TTC ATC GTC TT-3' \\
\hline \multirow[t]{2}{*}{ Thioredoxin 1} & TXN1 & NM_011660 & 315-484 & 170 & (F) 5'-AAG CCC TС ТTC САT TCC CT-3' \\
\hline & & & & & (R) 5'-CCT TGT TAG CAC CGG AGA AC-3' \\
\hline \multirow[t]{2}{*}{ 18S RNA } & RN18S & NR_003278 & $1194-1294$ & 101 & (F) 5'-TAA AGG AAT TGA CGG AAG GG-3' \\
\hline & & & & & (R) 5'-CTG TCA ATC CTG TCC GTG TC-3' \\
\hline
\end{tabular}

doi:10.1371/journal.pone.0004968.t004

mole of free TNB with the extinction coefficient $13.6 \mathrm{mM}^{-1} \mathrm{~cm}^{-1}$. For accessing the activity of Trx, assays were performed as above with the similar reaction cocktail except that $600 \mathrm{nM}$ rat TrxR1 but not $\operatorname{Trx} 1$ was included. Reaction solutions without TrxR 1 were used as the control.

\section{Data analysis and statistics}

All experiments were performed with six to eight samples per group, and all results were derived from at least three independent experiments. Data are shown as mean values \pm standard deviation (SD). Comparison between groups was done using Student's unpaired t-test. Tumor latency was analysed using a KaplanMeier survival analysis followed by log rank tests. In all statistical comparisons, $\mathrm{P}<0.05$ was used to indicate a significant difference. Note that for the ex vivo and in vitro experiments, while tumor cells derived from male and female mice showed similar characteristics in both FVB/N and C57BL/6J backgrounds, only results derived from the tumor cells of female FVB/N mice were shown. 


\section{Acknowledgments}

We thank Dr Keith Leung and Prof. Kathy Cheah for helping with the embryo re-derivation experiment. Adiponectin knockout mice were kindly provided by Dr. Lawrence Chan at Baylor College of Medicine.

\section{References}

1. Pischon T, Nothlings U, Boeing H (2008) Obesity and cancer. Proc Nutr Soc 67: $128-145$.

2. McTiernan A (2005) Obesity and cancer: the risks, science, and potential management strategies. Oncology (Williston Park) 19: 871-881; discussion 881872, 885-876.

3. Bray GA (2004) Medical consequences of obesity. J Clin Endocrinol Metab 89: 2583-2589.

4. Housa D, Housova J, Vernerova Z, Haluzik M (2006) Adipocytokines and cancer. Physiol Res 55: 233-244.

5. Baillargeon J, Rose DP (2006) Obesity, adipokines, and prostate cancer (review). Int J Oncol 28: 737-745.

6. Berstein LM (2005) [Hormones of adipose tissue (adipocytokines): ontogenetic and oncologic aspects]. Adv Gerontol 16: 51-64.

7. Rose DP, Komninou D, Stephenson GD (2004) Obesity, adipocytokines, and insulin resistance in breast cancer. Obes Rev 5: 153-165.

8. Wang Y, Lam KS, Yau MH, Xu A (2008) Post-translational modifications of adiponectin: mechanisms and functional implications. Biochem J 409: 623-633.

9. Trujillo ME, Scherer PE (2005) Adiponectin-journey from an adipocyte secretory protein to biomarker of the metabolic syndrome. J Intern Med 257: $167-175$.

10. Barb D, Williams CJ, Neuwirth AK, Mantzoros CS (2007) Adiponectin in relation to malignancies: a review of existing basic research and clinical evidence. Am J Clin Nutr 86: s858-866.

11. Schaffler A, Scholmerich J, Buechler C (2007) Mechanisms of disease: adipokines and breast cancer - endocrine and paracrine mechanisms that connect adiposity and breast cancer. Nat Clin Pract Endocrinol Metab 3: 345-354.

12. Vona-Davis L, Rose DP (2007) Adipokines as endocrine, paracrine, and autocrine factors in breast cancer risk and progression. Endocr Relat Cancer 14: 189-206.

13. Wang Y, Lam KS, Xu A (2007) Adiponectin as a negative regulator in obesityrelated mammary carcinogenesis. Cell Res 17: 280-282.

14. Mistry T, Digby JE, Desai KM, Randeva HS (2007) Obesity and prostate cancer: a role for adipokines. Eur Urol 52: 46-53.

15. Kelesidis I, Kelesidis T, Mantzoros CS (2006) Adiponectin and cancer: a systematic review. Br J Cancer 94: 1221-1225.

16. Koerner A, Kratzsch J, Kiess W (2005) Adipocytokines: leptin-the classical, resistin-the controversical, adiponectin-the promising, and more to come. Best Pract Res Clin Endocrinol Metab 19: 525-546.

17. Kaklamani VG, Sadim M, Hsi A, Offit K, Oddoux C, et al. (2008) Variants of the adiponectin and adiponectin receptor 1 genes and breast cancer risk. Cancer Res 68: 3178-3184.

18. Korner A, Pazaitou-Panayiotou K, Kelesidis T, Kelesidis I, Williams CJ, et al. (2007) Total and high-molecular-weight adiponectin in breast cancer: in vitro and in vivo studies. J Clin Endocrinol Metab 92: 1041-1048.

19. Mantzoros C, Petridou E, Dessypris N, Chavelas C, Dalamaga M, et al. (2004) Adiponectin and breast cancer risk. J Clin Endocrinol Metab 89: 1102-1107.

20. Tian YF, Chu CH, Wu MH, Chang CL, Yang T, et al. (2007) Anthropometric measures, plasma adiponectin, and breast cancer risk. Endocr Relat Cancer 14: 669-677.

21. Tworoger SS, Eliassen AH, Kelesidis T, Colditz GA, Willett WC, et al. (2007) Plasma adiponectin concentrations and risk of incident breast cancer. J Clin Endocrinol Metab 92: 1510-1516.

22. Miyoshi Y, Funahashi T, Kihara S, Taguchi T, Tamaki Y, et al. (2003) Association of serum adiponectin levels with breast cancer risk. Clin Cancer Res 9: 5699-5704.

23. Chen DC, Chung YF, Yeh YT, Chaung HC, Kuo FC, et al. (2006) Serum adiponectin and leptin levels in Taiwanese breast cancer patients. Cancer Lett 237: 109-114.

24. Kang JH, Yu BY, Youn DS (2007) Relationship of serum adiponectin and resistin levels with breast cancer risk. J Korean Med Sci 22: 117-121.

25. Pfeiler GH, Buechler C, Neumeier M, Schaffler A, Schmitz G, et al. (2008) Adiponectin effects on human breast cancer cells are dependent on 17-beta estradiol. Oncol Rep 19: 787-793.

26. Grossmann ME, Nkhata KJ, Mizuno NK, Ray A, Cleary MP (2008) Effects of adiponectin on breast cancer cell growth and signaling. Br J Cancer 98: $370-379$.

27. Arditi JD, Venihaki M, Karalis KP, Chrousos GP (2007) Antiproliferative effect of adiponectin on MCF7 breast cancer cells: a potential hormonal link between obesity and cancer. Horm Metab Res 39: 9-13.

28. Wang Y, Lam JB, Lam KS, Liu J, Lam MC, et al. (2006) Adiponectin modulates the glycogen synthase kinase-3beta/beta-catenin signaling pathway and attenuates mammary tumorigenesis of MDA-MB-231 cells in nude mice. Cancer Res 66: 11462-11470.

\section{Author Contributions}

Conceived and designed the experiments: AX YW. Performed the experiments: JBL KHC JL YW. Analyzed the data: JBL KHC AX YW. Contributed reagents/materials/analysis tools: AX KL NSW RTM PS GC YW. Wrote the paper: JBL KHC YW.

29. Dieudonne MN, Bussiere M, Dos Santos E, Leneveu MC, Giudicelli Y, et al. (2006) Adiponectin mediates antiproliferative and apoptotic responses in human MCF7 breast cancer cells. Biochem Biophys Res Commun 345: 271-279.

30. Kang JH, Lee YY, Yu BY, Yang BS, Cho KH, et al. (2005) Adiponectin induces growth arrest and apoptosis of MDA-MB-231 breast cancer cell. Arch Pharm Res 28: 1263-1269.

31. Nakayama S, Miyoshi Y, Ishihara H, Noguchi S (2007) Growth-inhibitory effect of adiponectin via adiponectin receptor 1 on human breast cancer cells through inhibition of S-phase entry without inducing apoptosis. Breast Cancer Res Treat.

32. Hebbard LW, Garlatti M, Young LJ, Cardiff RD, Oshima RG, et al. (2008) Tcadherin supports angiogenesis and adiponectin association with the vasculature in a mouse mammary tumor model. Cancer Res 68: 1407-1416.

33. Jarde T, Caldefie-Chezet F, Damez M, Mishellany F, Buechler C, et al. (2008) Antagonistic proliferative activities of adiponectin and leptin in breast cancer: study on MCF7 cells. Proc Nutr Soc 67: E184.

34. Chaussade C, Rewcastle GW, Kendall JD, Denny WA, Cho K, et al. (2007) Evidence for functional redundancy of class IA PI3K isoforms in insulin signalling. Biochem J 404: 449-458.

35. DeFeo-Jones D, Barnett SF, Fu S, Hancock PJ, Haskell KM, et al. (2005) Tumor cell sensitization to apoptotic stimuli by selective inhibition of specific Akt/PKB family members. Mol Cancer Ther 4: 271-279.

36. Tamura T, Stadtman TC (2002) Mammalian thioredoxin reductases. Methods Enzymol 347: 297-306.

37. Guy CT, Cardiff RD, Muller WJ (1992) Induction of mammary tumors by expression of polyomavirus middle $\mathrm{T}$ oncogene: a transgenic mouse model for metastatic disease. Mol Cell Biol 12: 954-961.

38. Ma K, Cabrero A, Saha PK, Kojima H, Li L, et al. (2002) Increased beta oxidation but no insulin resistance or glucose intolerance in mice lacking adiponectin. J Biol Chem 277: 34658-34661.

39. Varticovski L, Hollingshead MG, Robles AI, Wu X, Cherry J, et al. (2007) Accelerated preclinical testing using transplanted tumors from genetically engineered mouse breast cancer models. Clin Cancer Res 13: 2168-2177.

40. Georgescu MM, Kirsch KH, Akagi T, Shishido T, Hanafusa H (1999) The tumor-suppressor activity of PTEN is regulated by its carboxyl-terminal region. Proc Natl Acad Sci U S A 96: 10182-10187.

41. Lu J, Chew EH, Holmgren A (2007) Targeting thioredoxin reductase is a basis for cancer therapy by arsenic trioxide. Proc Natl Acad Sci U S A 104: 12288-12293.

42. Sorlie T, Perou CM, Tibshirani R, Aas T, Geisler S, et al. (2001) Gene expression patterns of breast carcinomas distinguish tumor subclasses with clinical implications. Proc Natl Acad Sci U S A 98: 10869-10874.

43. Livasy CA, Perou CM, Karaca G, Cowan DW, Maia D, et al. (2007) Identification of a basal-like subtype of breast ductal carcinoma in situ. Hum Pathol 38: 197-204.

44. Carnero A, Blanco-Aparicio C, Renner O, Link W, Leal JF (2008) The PTEN/ $\mathrm{PI} 3 \mathrm{~K} / \mathrm{AKT}$ signalling pathway in cancer, therapeutic implications. Curr Cancer Drug Targets 8: 187-198.

45. Meuillet EJ, Mahadevan D, Berggren M, Coon A, Powis G (2004) Thioredoxin1 binds to the C2 domain of PTEN inhibiting PTEN's lipid phosphatase activity and membrane binding: a mechanism for the functional loss of PTEN's tumor suppressor activity. Arch Biochem Biophys 429: 123-133.

46. Dillon RL, White DE, Muller WJ (2007) The phosphatidyl inositol 3-kinase signaling network: implications for human breast cancer. Oncogene 26: 1338-1345.

47. Tamguney T, Stokoe D (2007) New insights into PTEN. J Cell Sci 120: 4071-4079.

48. Leslie NR, Downes CP (2004) PTEN function: how normal cells control it and tumour cells lose it. Biochem J 382: 1-11.

49. Arnér ES, Holmgren A (2000) Physiological functions of thioredoxin and thioredoxin reductase. Eur J Biochem 267: 6102-6109.

50. Hui ST, Andres AM, Miller AK, Spann NJ, Potter DW, et al. (2008) Txnip balances metabolic and growth signaling via PTEN disulfide reduction. Proc Natl Acad Sci U S A 105: 3921-3926.

51. Zhao H, Cui Y, Dupont J, Sun H, Hennighausen L, et al. (2005) Overexpression of the tumor suppressor gene phosphatase and tensin homologue partially inhibits wnt-1-induced mammary tumorigenesis. Cancer Res 65: 6864-6873.

52. Kim SE, Lee WJ, Choi KY (2007) The PI3 kinase-Akt pathway mediates Wnt3a-induced proliferation. Cell Signal 19: 511-518.

53. Turecková J, Kucerová D, Vojtechová M, Sloncová E, Tuhácková Z (2006) Expression of beta-catenin is regulated by PI-3 kinase and sodium butyrate in colorectal cancer cells. Int J Mol Med 17: 69-75.

54. Naito AT, Akazawa H, Takano H, Minamino T, Nagai T, et al. (2005) Phosphatidylinositol 3-kinase-Akt pathway plays a critical role in early cardiomyogenesis by regulating canonical Wnt signaling. Circ Res 97: 144-151. 
55. Zhou M, Xu A, Tam PK, Lam KS, Chan L, et al. (2008) Mitochondrial dysfunction contributes to the increased vulnerabilities of adiponectin knockout mice to liver injury. Hepatology 48: 1087-1096.

56. Liu J, Lam JB, Chow KH, Xu A, Lam KS, et al. (2008) Adiponectin stimulates Wnt inhibitory factor-1 expression through epigenetic regulations involving the transcription factor specificity protein 1. Carcinogenesis 28: 163-167.
57. Bloomfield KL, Osborne SA, Kennedy DD, Clarke FM, Tonissen KF (2003) Thioredoxin-mediated redox control of the transcription factor Sp1 and regulation of the thioredoxin gene promoter. Gene 319: 107-116. 